\title{
Sociologické aspekty komercializace fotbalu: nástin problematiky ${ }^{*}$
}

\author{
KAREL HaNuš**
}

\section{Sociological Aspects of the Commercialization of Football: A Sketch of the Subject}

\begin{abstract}
A goal of this article is formulating of selected sociological contexts of the commerialization of football in context of modernization of society and the generalization of market (Polanyi). Close attention is paid to the situation in England which was in large measure determining for development of this phenomenon, altghouh other regions are not neglected too. Integration of football into the market economy has been coming through gradational adaptation of basic institutions to necessities of market in place of previous non-market motivations and forms, integration of football into the consumer culture through mass medias (including development of sponsorship), constitution of football as a gainful job and then deregulation of football labour market, change of social status of the best players and upward social mobility of the professional players, transformations of social identities of football fans and in end result creation of the relatively autonomus unequal economic structure both in national and world scale with its imanent financial problems. On the other hand, in society there still exist various forms of back-pressure against relative dominance of market and private corporations.
\end{abstract}

Keywords: football, commercialization, professionalization, identity, television, modernization, capitalism

\section{Úvod}

Moderní fotbal se od svého vzniku v 19. století rozšíril do všech zemí světa a jednoznačně se stal nejpopulárnějším sportovním odvětvím. Zároveň došlo k vytvoření složité, vnitřně diferencované struktury, zahrnující vysoce organizovaný profesionalizovaný vrcholový sport, amatérské výkonnostní soutěže, více či méně pravidelnou volnočasovou aktivitu i zcela pasivní sledování. Tato vnitřní diferenciace a globální rozššření moderního fotbalu jsou ve srovnání s jeho předmoderními formami důsledkem mnohostranného působení modernizačních procesů, způsobujících jeho postupnou transformaci a umožňujících jeho institucionalizaci uvnitř moderní společnosti.

Jedním z klíčových procesů, podle řady autorů rozhodujícím, byl bezesporu vznik a rozšśření kapitalismu. Podle Karla Polanyiho [2006] se v klíčovém období tzv. velké transformace odehrály rozhodující momenty přechodu ze společnosti s trhem na společnost tržní a přeměny práce (člověka) a půdy (př́rody) na zboží. V důsledku toho se podstatně zvýšila schopnost tržních mechanismů a tedy i jeho nejvlivnějších aktérů ovlivňovat jednotlivé oblasti společenského života. Rozšíření tržní ekonomiky se zprvu týkalo zejména oblasti výroby, postupem doby však stále více tržní mechanismy

* Tento text je upravenou a rozšířenou verzí části diplomové práce na téma Fotbal a společenská modernizace [2008a], oceněné Cenou Edvarda Beneše třetího stupně pro rok 2009.

** Mgr. Karel Hanuš, Středisko iberoamerických studií, Hybernská 3, 11000 Praha 1.

E-mail: hanusk@email.cz 
zasahovaly i do oblasti kultury, což umocnil několikafázový rozmach masových médií. Antonio Gramsci tak již na konci dvacátých let minulého století píše, že kapitalismus dobudoval svoji průmyslovou základnu a nyní je ekonomický růst poháněn zejména mechanismy spotřeby, s čímž souvisí rostoucí význam kultury jako nástroje mocenské kontroly, nebot vzorce masové spotřeby lze naučit, ale nikoli vynutit [Gramsci in Znebejánek 1997: 36-37]. Současného vrcholu dosáhl tento proces v éře tzv. neoliberalismu, kdy se z velkých korporací, zejména těch zaměřených na produkci spotřebního zboží a služeb, staly globální značky, jejichž udržování a expanze se v nejednom případě stalo prvořadým cílem namísto dosavadního zaměření na výrobu [Kleinová 2005]. Úspěšnost těchto strategií je umožněna mimo jiné díky proměnám sociálna, kdy se po rozpadu tradičních sociálních skupin začaly vytvářet identity na odlišném základě. $\mathrm{V}$ rámci této proměny dochází k mnohovrstevnatému procesu individualizace, zakládajícímu nároky na individuální seberealizaci, stále více určující pro legitimizaci západního společenského systému [Honneth 2007: 181]. Na formování individuálních identit se výrazně podílí trh, což vede Zygmunta Baumana k opakovanému konstatování poněkud vyhrocené teze, že si postmoderní člověk svou identitu kupuje [srv. např. Bauman 1995: 134].

Postupné rozšiřování trhu s imanentními sklony ke komodifikaci různých oblastí společenského života se projevilo i ve fotbale. Zpočátku zejména v Anglii, kde moderní fotbal vznikl a odkud se, i vzhledem k politicko-ekonomické hegemonii Britského impéria, rozšíril do dalších zemí Evropy a ostatních kontinentů. Masová popularita fotbalu vytvořila předpoklady pro rozvoj s ním souvisejícího podnikání. Postupné přizpůsobování fotbalu požadavkům trhu zahrnuje změnu struktury, chodu i cílů a strategií fotbalových organizací (zejména klubů, ale také národních a nadnárodních svazů a federací), přeměnu vrcholového fotbalu na placené zaměstnání (s rostoucím uznáním i společenským a finančním ohodnocením), transformaci identit fotbalových fanoušků, začlenění fotbalu do masové a posléze globální konzumní kultury a v konečném důsledku vytvoření relativně autonomního ekonomického odvětví s vnitřně velmi nerovnou strukturou (v globální i národní perspektivě) a specifickými problémy, přitom ale začleněného do globální kapitalistické ekonomiky. Tlaky na komercializaci fotbalu však zároveň téměř vždy vyvolávaly nějakou, více či méně intenzivní formu protitlaku, ovlivněnou specifickým společensko-historickým kontextem.

Z makrosociologického hlediska tak analýza komercializace fotbalu umožňuje uvažovat o různých aspektech vztahu ekonomiky a společnosti, kterému je v soudobých teoretických debatách věnována značná pozornost. Jakkoli je tedy v této studii kladen důraz na vývoj v Anglii, který měl nesporný vliv na situaci v ostatních zemích, pozornost je věnována i dalším regionům. Na první pohled možná disparátní soubor př́ikladů z různých zemí i období slouží k ilustraci jednotlivých jevů. Přirozeně nemá ambici podat vyčerpávající výklad historické sociologie komercializace fotbalu v globální perspektivě, nýbrž spíše naznačit podobnosti i rozdíly v povaze tohoto procesu v proměnlivém společensko-historickém kontextu. Relativně široce vymezený předmět studie, snažící se postihnout základní souvislosti zkoumaného jevu, může napomoci k reflexi tématu v širším rámci, než jaký nabízí relativně úzké hranice subdisciplíny sociologie sportu, na které bývá sociologie fotbalu redukována. To platí i pro specifické prostředí české sociologie, kde se fotbal nachází na okraji zájmu i v rámci už tak marginální sociologie sportu. 


\section{Fotbal, společnost a ekonomika}

Nahlížíme-li na fotbal (a sport obecně) prizmatem vztahu ekonomiky a společnosti, je možné na základě abstrakce rozlišit dva ideálně typické modely organizace celého sportovního odvětví: komerční a sociokulturní. V prvně jmenovaném se celá organizační struktura sportu přizpůsobuje požadavkům trhu, hlavním cílem zde je dosahování zisku. Za prototyp komerčního modelu bývají považovány sportovní soutěže ve Spojených státech amerických. Ve druhém případě převažuje vliv mimoekonomických faktorů a motivací a sport se považuje za jedinečný kulturní fenomén, mající hodnotu sám o sobě. K tomuto pojetí se více blíží evropská sportovní praxe a explicitně je vyjádřeno v Bílé knize o sportu, kterou zveřejnila v roce 2007 Evropská komise. ${ }^{1}$ Základní rozdíly obou modelů jsou znázorněny $\mathrm{v}$ Tabulce 1 :

\begin{tabular}{|l|l|l|}
\hline & evropský (sociokulturní) & americký (komerční) \\
\hline organizační motivy & sportovní soutěž & zisk \\
\hline ligová struktura & $\begin{array}{l}\text { otev̌rená pyramida; } \\
\text { postup a sestup }\end{array}$ & uzavřená liga; ohrazený kruh \\
\hline role vládnoucího orgánu & $\begin{array}{l}\text { vertikální solidarita; } \\
\text { sport pro všechny }\end{array}$ & $\begin{array}{l}\text { maximalizace zisku; podpora } \\
\text { elitních hvězd jako celebrit }\end{array}$ \\
\hline kulturní identita & $\begin{array}{l}\text { národní ligy, lokální týmy; } \\
\text { odpor k přemístování týmů } \\
\text { a transnacionálním ligám }\end{array}$ & $\begin{array}{l}\text { transnacionální či globální } \\
\text { ligy, licence bez závazkủ }\end{array}$ \\
\hline mezinárodní soutěže & důležité pro národní identity & $\begin{array}{l}\text { neexistují, nebo jsou } \\
\text { nevýznamné }\end{array}$ \\
\hline struktura vlády & $\begin{array}{l}\text { jediný reprezentativní } \\
\text { federální orgán }\end{array}$ & liga nebo komisař \\
\hline
\end{tabular}

Tabulka č. 1: Europský a americký model sportu

Zdroj: Foster, Ken. [2005]. Alternative Models for the Regulation of Global Sports. In. Allison, Lincoln (ed.). The Global Politics of Sport: The Role of Global Institutions in Sport. London, New York: Routledge, s. 74.

1 V úvodu tohoto dokumentu Komise deklaruje evropské pojetí sportu, v jehož rámci zdůrazňuje jeho společenskou roli a význam při předávání kulturních hodnot (např. tolerance, solidarita, týmový duch, fair play). V tomto kontextu je třeba vyzdvihnout skutečnost, že podle autorů dokumentu se mezi hrozby současnému sportu řadí i komerční tlaky a bezohledné využívání mladých hráčů. I v samotném textu je výrazně větší pozornost věnována otázkám společenské role a organizace sportu spíše než jeho hospodářskému rozměru. V textu konkrétně stojí: „Sport představuje společenský a ekonomický jev narůstajícího významu, jenž význačným způsobem přispívá k naplňování strategických cílů solidarity a prosperity, vytyčených Evropskou unií. Olympijský ideál rozvoje sportu na podporu míru a porozumění mezi jednotlivými národy a kulturami a rovněž výchovy mladých lidí se zrodil v Evropě a záštitu nad ním převzal Mezinárodní olympijský výbor a Evropské olympijské výbory. Evropští občané podléhají kouzlu sportu a většina jej pravidelně aktivně provozuje. Vytvářejí se při něm důležité hodnoty, jako je např́klad týmový duch, solidarita, tolerance a smysl pro fair play, př́ispívá k osobnímu rozvoji a naplnění. Podporuje aktivní zapojení občanů EU do společnosti, a pomáhá tak rozvíjet aktivní občanství. Komise bere na vědomí zásadní roli sportu v evropské společnosti, a to zvláště tehdy, kdy je nutné, aby se přiblížila občanům a řešila otázky, které se jich bezprostředně týkají. Sport nicméně čelí i novým hrozbám a překážkám, které se v evropské společnosti objevily, jako jsou komerční tlaky, bezohledné využívání mladých hráčů, doping, rasismus, násilí, korupce a praní špinavých peněz [Bílá kniha o sportu 2007: 2].“ 
Uznání společensko-kulturní role sportu v evropských zemích nicméně neznamená, že by zde tržní ekonomika nijak neovlivňovala podobu sportovních soutěží. Většina moderních sportovních odvětví (v čele s fotbalem) naopak byla více či méně zkomercializována. ${ }^{2}$ Ve většině zemí převládl v organizaci fotbalu díky dominanci Evropy model evropský, přestože se pod nálepkou amerikanizace v rámci globalizačních procesů často přisuzuje větší význam severoamerickému vlivu. Někteří autoři a představitelé největších klubů však v současnosti předkládají návrhy na řešení ekonomických problémů, které by evropský fotbal více přiblížily americkému pojetí.

Pod termínem komercializace fotbalu se rozumí přeměna fotbalu na zboží, jeho začlenění do ekonomiky jako celku a přizpůsobení logice jejího fungování. Tento proces probíhá na pozadí generalizace trhu a emancipace ekonomického systému, dřive zcela podřízeného systému sociálnímu. Sledování a hraní fotbalu se postupem doby stalo předmětem tržní směny. K vytvoření fotbalového průmyslu výrazně přispěl rozvoj masových médií, který díky všeobecnému zpř́stupnění fotbalu vytvořil prostor pro jeho komerční využití. $\mathrm{V}$ některých bohatších zemích $\mathrm{s}$ větším trhem $\mathrm{v}$ průběhu několika posledních desetiletí došlo k rozsáhlé akumulaci kapitálu, především u největších fotbalových klubů a dalších aktérů, jejichž obchodní činnost s fotbalem souvisí. Rostoucí ekonomická síla největších klubů vytváří tlak na existující institucionální uspořádání, obdobně jako tomu je v současné době ve vztahu mezi ekonomikou a politikou obecně. Kromě existence tržní ekonomiky patří mezi zdánlivě samozřejmé strukturální předpoklady fungujícího fotbalového průmyslu také institucionální zakotvení, existence pevných pravidel a organizací, které jsou schopné efektivně dohlížet na jejich dodržování (funkcionální analogie státu a práva ve vztahu k ekonomice). Pokud tyto předpoklady nejsou naplněny, odpovídá profesionální fotbal spíše poměrům předmoderního kořistnického kapitalismu. ${ }^{3}$

2 Za specifickou variantu evropského modelu lze považovat organizaci sportu v někdejších státně socialistických zemích. Komerční aspekty zde byly potlačeny ve prospěch prvků sociokulturních a politických, i zde však např. v oblasti hráčských přestupů navzdory pevně stanoveným oficiálním částkám existovaly elementární tržní mechanismy. Politické snahy využít fotbal (a sport obecně) pro potřeby legitimizace nového režimu v padesátých letech a vytvoření a posléze udržování socialistické kulturní hegemonie, projevující se v Československu snahou o sovětizaci fotbalu, např. ve formě přechodu na systém jaro-podzim (praktikovaném v SSSR kvůli dlouhému zimnímu období) v letech 1949-1957, pokusu o reorganizaci tělovýchovných organizaci podle průmyslových odvětví v roce 1953, kdy byla administrativně vyřazena a nově zařazena polovina týmů, či změny vlastníků a názvů klubů [Jeřábek 1991: 259-277], nevedly, snad s částečnou výjimkou organizačních motivů, ke změně základních prvků organizační struktury evropského modelu, jak jej vymezuje Foster.

3 Jako př́klad lze uvést kolumbijskou „ligu eldorádo“ z padesátých let minulého století, kdy místní kluby v čele s Millonarios Bogota často získávaly hráče z jiných soutěží pirátským způsobem bez poplatků za přestupy. „Liga eldorádo“, žijící z peněz drogových kartelů a nepodléhající regulaci ze strany kolumbijské fotbalové federace ani FIFA, byla v době hráčské stávky v argentinské lize (1947-1953) nejkvalitnější klubovou soutěží na světě [Bedřich 2006: 32-33]. V některých rysech obdobná situace nastala také na Ukrajině, která se krátce po pádu socialismu osamostatnila, propadla se do hluboké ekonomické krize a jen s velkými obtížemi se jí dařilo vymáhat dodržování práva. Dynamo Kyjev se v roce 1989 stalo prvním plně profesionálním klubem v SSSR. Tehdejší vedení se rozhodlo udělat z Dynama bohatý klub. Nejprve zakládalo společné podniky, do nichž vkládalo část majetku. Zisk těchto společností byl osvobozený od daní, protože Dynamo bylo teoreticky sportovní oddíl. Díky tomu klub získával měsíčně př́imy v řádu milionů dolarů, takže mohl být úspěšný i bez fotbalu. Na ochranu svých zájmů klubové vedení spolupracovalo se šéfy mafie, stranickými funkcionáři a jejich rodinami a díky pravidelným vystoupením v zahraničí i se západními obchodníky. Právě zahraniční společnosti jsou zdrojem kapitálu, Dynamo je pouze zárukou nižších daní, kontaktů a dobrého jména na ukrajinském trhu. Dynamo Kyjev tehdy disponovalo většími finančními zdroji než ukrajinská vláda, takže díky př́ležitostným „darům národu“ získalo povolení na vývoz dílů jaderných zbraní, 
V této studii je větší pozornost věnována procesu komercializace fotbalu v Anglii, kde se projevil nejdříve, nejvýrazněji a nebyl poznamenán zásadními vývojovými diskontinuitami, a evropským klubovým soutěžím, v menší míře pak ostatním regionům.

\section{Komercializace fotbalu v Anglii}

Nebývalé šíření popularity fotbalu mezi anglickými dělníky (zvláště ze severu a středu Anglie) v sedmdesátých a osmdesátých letech 19. století vyvolalo rostoucí potřebu fotbal aktivně provozovat i pasivně sledovat. Fotbal se stal oblíbenou lidovou zábavou a pro své příznivce zdrojem kulturního významu, což mělo několik významných následků: založení pravidelné soutěže, vznik primitivních stadionů, zpoplatnění přítomnosti na stadionech a vyšší nároky na předzápasovou přípravu hráčů, což vytvořilo předpoklady pro zavedení profesionalismu [Williams - Neatrour 2002: 1-2].

Podle Stephena Dobsona a Johna Goddarda lze rozlišit tř̌i základní etapy ve vývoji komercializace anglického fotbalu po 1 . světové válce. První etapu ve dvacátých až padesátých letech charakterizuje uniformita finanční struktury klubů na všech úrovních ligy, regulace vstupného a platu hráčů. V souvislosti se vzestupem životní úrovně v poválečném období stoupaly u nižších vrstev požadavky na volnočasové aktivity a stávající limity se ukázaly jako neudržitelné. V roce 1961 proto došlo ke zrušení maximální povolené výše platu hráčů a o dva roky později byl reformován přestupní řád, což vedlo k postupnému růstu nerovností mezi kluby v jednotlivých soutěžích a vzniku proměnlivější ekonomické struktury klubů. V mezidobí od poloviny sedmdesátých let do konce osmdesátých let poklesl kvưli sociodemografickým změnám a vlně chuligánství zájem o fotbal a návštěvnost utkání v nejvyšších soutěžích, bylo ohroženo přežití mnoha menších klubů a pokračoval růst nerovností. Po sérii katastrof v Bruselu, Bradfordu a Hillsborough ${ }^{4}$ byla $\mathrm{v}$ anglickém fotbale uskutečněna série reforem, která přispěla $\mathrm{k}$ jeho rehabilitaci, dalšímu ostrému růstu nerovností a negativním dopadům na malé kluby. Mezi pozitiva patřil pokrok v kvalitě vysílání, nové stadiony (všechna místa k sezení), vytlačení chuli-

dvou tun zlata ročně ( $v$ době hluboké krize ukrajinské ekonomiky) a vzácných kovů včetně platiny [Kuper 2005: 80-84].

4 Dne 29. května 1985 se na Heyselově stadionu v Bruselu konalo finále Ligy mistrů (PMEZ) mezi Juvetusem Turín a FC Liverpool, před kterým skupinky podnapilých britských rowdies napadly kameny italské fanoušky. Následná panika v italském sektoru zapříčinila prolomení ochranné zdi. V důsledku zřícení zdi, ušlapání či samotné bitky zahynulo 42 lidí a dalších přibližně 250 bylo zraněno. Celou událost zachytily televizní kamery a díky tomu bylo možné identifikovat skupiny (v některých případech ozbrojených) liverpoolských chuligánů, kteří tragédii vyprovokovaly a podněcovaly útoky proti prchajícím italským fanouškům. Celá událost se stala symbolem fotbalového chuligánství, vyvolala širokou diskusi, přísné tresty a změny v bezpečnostních opatřeních na stadionech. Anglické kluby byly až do odvolání vyloučeny ze všech evropských soutěží, nepřítomnost anglických klubů v evropských pohárech nakonec trvala pět let [Mareš - Smolík - Suchánek 2004: 52-53]. Dva týdny před bruselskými událostmi zahynulo 53 fanoušků při požáru na stadionu v Bradfordu. Další tragédie nesouvisející s chuligánstvím se odehrála 15. dubna 1989 na stadionu Hillsborough v Sheffieldu při semifinále Anglického poháru mezi Liverpoolem a Nottingamem Forest. V důsledku zmatků u turniketů vnikly do plně obsazeného stadionu tři tisíce liverpoolských fanoušků bez vstupenek. Policisté a pořadatelé je $\mathrm{v}$ obavách $\mathrm{z}$ tlaku davu vpustili dovnitř. $\mathrm{V}$ dolní části přeplněného sektoru, který byl v rámci protichuligánských opatření obehnán bariérami a pevnými ploty, bylo ušlapáno, umačkáno nebo udušeno 95 liverpoolských fanoušků. Po této události byly ploty a bariéry zrušeny, byly zavedeny kamerové systémy snímající nyní neizolované jednotlivé sektory fanoušků a podle Taylorovy zprávy bylo doporučeno, aby kluby ve vyšších divizích měly na stadionech pouze místa k sezení [Mareš - Smolík - Suchánek 2004: 69]. 
gánství a zlepšení kvality hry díky příchodu cizinců. Liberalizace pracovního trhu vedla k růstu platů nejlepších hráčů a částek za přestupy [Dobson - Goddard 2001: 123-124].

Na druhé straně ale došlo k proměnám ve vztazích mezi fanoušky a kluby i mezi fanoušky navzájem a zároveň k výraznému nárůstu exkluzivity fotbalu. Vyloučení chudších obyvatel z participace na fotbalu je způsobeno vysokými cenami za fotbalovou výstroj, předměty s klubovou symbolikou, poplatky za vstup na hřiště i na stadiony ${ }^{5}$ či měsíčním předplatným satelitního vysílání. Kluby k těmto nerovnostem přispívají vlastní protržní politikou. Základnu fanoušků na stadionech tak na místo dělníků nyní tvoří mladí muži anebo rodiny ze středních vrstev. Uvnitř nové střední třídy lze ve vztahu k proměnám soudobého fotbalu rozlišit dva základní proudy: tradicionalistický (převažující na severu Anglie) a spíše jihoangličtí arrivistes, vnímající soudobý vývoj pozitivněji [Giulianotti 1999: 150-151, 164-165].

\section{Vlastnická struktura klubů}

S rostoucí komercializací fotbalu docházelo zároveň ke změně vlastnické struktury, organizace a cílového zaměření klubů. Fotbalové kluby zpravidla zpočátku vznikaly jako náboženské, dělnické, politické či jiné nekomerční subjekty, později se však postupně přetvářely na (nestandardní, často ztrátové) obchodní organizace. ${ }^{6}$ Prvním klubem, který se přeměnil na společnost s ručením omezeným, byl Birmingham City v roce 1887. Tento model se rychle rozšríril i mezi ostatními profesionálními kluby v Anglii a byl doprovázen pozvolným přesunem kontroly od viceprezidentů - mecenášů a členů klubu k nedělnickým podílníkům a specializovaným manažerům [Hargreaves 1987: 70]. Tradiční model fotbalového klubu jakožto rodinného podniku, často patřícího majitelům největší továrny ve městě (např. rodina Agnelliů vlastnící automobilku Fiat a Juventus Turín), kdy členové jeho vedení jsou zároveň jeho vlastníky, stále ještě zcela nevymizel, postupně je však nahrazován akciovými společnostmi s odděleným vedením a vlastnictvím. V podmínkách globalizace a volného pohybu kapitálu sílí trend k privatizaci klubů a jejich včleněnní do tržních vztahů [Giulianotti 1999: 87-88]. Kalevi Heinilä na příkladu finských sportovních klubů ukazuje, jak se vzhledem k působení vnějších vlivů, především postupující komercializaci, sportovní kluby transformují z obecně prospěšných organizací na servisní typ organizace zaměřený na služby zákazníkům (veřejnosti a divákům). Nutnost dostát imperativům trhu vyžaduje odklon od hodnot a ideologií, důraz na efektivitu a výkon a profesionalizovaný management. Motivace členů klubů vychází spíše z kalkulace zisků a ztrát než ze samotného zájmu o sport [Heinilä 1989: 244-245].

Od osmdesátých let se u řady větších evropských klubů objevuje tendence k emisi vlastních akcií na burzu cenných papírů. Na jedné straně sice tento čin umožnil jednotlivým fanouškům získat vlastnický podíl v klubu (tzv. lidový kapitalismus), v praxi však

5 Jak uvádí Alan Evans, v posledních letech rostly ceny vstupenek v Anglii nepoměrně rychleji než průměrná mzda. Zatímco v roce 1977 byl průměrný plat 27554 liber ročně a průměrná cena nejlevnější vstupenky 4,3 libry, v roce 1992 činil tento poměr 28508 liber mzdy a 11,92 libry za vstupenku a v roce 2008 šlo již o 29993 liber průměrné roční mzdy a 28 liber průměrně za nejlevnější vstupenku [Evans in Making Football Affordable 2009].

6 Na podobném principu byla organizována i The Football Association (FA), ze které se sice v roce 1903 stala společnost s ručením omezeným s nominálním kapitálem 100 liber (2000 podílů), ale která usilovala o podporu fotbalu, nikoli tvorbu zisku. Jednotliví členové neměli povoleno vybírat dividendy, ani usilovat o kontrolu nad organizací [Pickford 1940-1941: 87]. 
klub kontrolují bohatí vlastníci a podíl jednotlivců spíše klesá. Z dlouhodobého hlediska ale byl vstup na burzu finančně výhodný pouze pro velké kluby (např. Manchester United), hodnota mnoha menších klubů naopak poklesla (např. Leicester City), což přispělo k dalšímu prohloubení rozdílů mezi jednotlivými kluby [Lee 1998: 36]. V Latinské Americe naproti tomu kluby často řídí jejich členská základna, platící měsíční či roční příspěvky. Předsedové klubů, volení na jeden rok, svou funkci mnohdy využívají pouze pro potřeby své politické kariéry [Giulianotti 1999: 87].

\section{Fotbal a masová média}

Rozvoj masových médií (zvláště televize) výrazně přispíval ke zvyšování popularity fotbalu od počátku jeho existence. Sportovní zpravodajství se patrně poprvé objevilo v britských a amerických novinách na konci devatenáctého století, v rádiu v průběhu meziválečného období a v televizi výrazněji až po 2. světové válce. Technické požadavky při tvorbě sportovních přenosů na jedné straně stimulovaly technologické inovace v televizním vysílání (opakované a zpomalované záběry, přibližování, barevnost), sport se na druhé straně stal důležitým prvkem při propagaci vylepšených televizí v šedesátých letech i později a napomohl tak k jejich rozšiření mezi širší vrstvy obyvatel. Úspěch televizního sportu spočívá v oboustranně výhodné symbióze: zatímco televize nabídla sportu široké publikum (v národním a posléze i globálním rozměru) a nové zdroje príijmu, sport nabídl televizi nevyčerpatelnou zásobu velkých událostí a divácky atraktivních podívaných. Výsledkem vzájemného propojení je tak přesun sportovních zážitků bezprostřednosti a nejistoty do soukromí diváků i vytváření nových celospolečenských rituálů. Větší kulturní viditelnost sportu zvyšuje jeho atraktivitu pro inzerenty, rostoucí př́imy z reklamy zvyšují cenu televizních práv a zároveň zlepšují vyjednávací pozici televizních společností. Jednotlivé národní asociace tak musí svůj chod i organizaci soutěží přizpůsobovat zájmům $z$ valné části soukromých televizí. Na nejvyšší úrovni se tento trend projevuje např. výběrem hostitelské země mistrovství světa, kdy perspektiva zisku v některých případech převažuje nad významem země ve světě fotbalu (např. mistrovství světa v USA v roce 1994 nebo v Japonsku a Jižní Koreji v roce 2002) [viz Whannel 2009: 206-210].

Podle Barnetta lze rozlišit tři etapy vývoje vztahu fotbalu a televize v Anglii. První období charakterizuje monopol BBC, kdy z televize do klubů proudí relativně málo peněz a panuje všeobecný konsensus o prioritě obecné př́stupnosti fotbalu a principu veřejné služby televize. Ve druhé fázi mezi sebou soutěží BBC a soukromá ITV a dochází k růstu ceny vysílacích práv. Ve třetí etapě, která trvá i v současnosti, následuje deregulace a nástup placené kabelové a satelitní televize [Barnett in Hare 2003: 151].

Rostoucí příjmy z televizních práv přiměly v roce 1992 největší anglické kluby k odtržení první divize Football League a založení Premier League, která by spadala přímo pod The Football Association. Cílem tohoto opatření bylo vymanění se z kontroly menších klubů z nižších soutěží, získání plné kontroly nad prodejem televizních práv a neochota dělit se s nimi o takto získané př́ijmy. Podobné motivy, jak bude řečeno později, vedly také k návrhům na vytvoření Superligy [Cave - Crandall 2001: F7-F8]. Pro ilustraci tržní hodnoty televizních práv lze uvést např. smlouvu mezi BSkyB ${ }^{7}$ a English

7 British Sky Broadcasting (BSkyB) vznikla sloučením konkurenčních BSB a Sky TV a stala se hlavním 
Premiership na pokrytí přímých přenosů z Premier League od roku 1997 po dobu čtyř let v ceně 670 milionů liber (předchozí pětiletá smlouva stála BSkyB 191,5 milionu liber). Pravděpodobně nejrentabilnější způsob televizního vysílání fotbalu pro vrcholové akce představuje tzv. pay-per-view systém zavedený poprvé v roce 1997 ve Francii, kdy divák platí poplatky za jednotlivé sledované sportovní akce, např. fotbalový zápas [Giulianotti 1999: 92-93]. Televizní společnosti se tak stále více stávají kanálem přesunu peněz od diváků k fotbalovým klubům. Malé kluby budou znevýhodněny, velké kluby budou profitovat díky své značce [Dobson - Goddard 2001: 439], a vzhledem k větším příjmům z prodeje televizních práv budou více nezávislé při jednání asociace s televizní společností [Lee 1998: 35].

Z logiky věci vyplývá, že vlastnický podíl ve velkých klubech je pro mediální společnosti vysoce výhodným artiklem, přesto však pouze ve dvou případech vlastní tyto společnosti většinový podíl. ${ }^{8} \mathrm{~V}$ USA je naproti tomu tato situace zcela běžná, a vrcholový sport tak ve vyšší míře podléhá zájmům trhu [Cave - Crandall 2001: F22].

Proti tzv. televizaci fotbalu, zvláště v její nejvíce komercializované podobě, jsou ovšem vznášeny četné námitky. Televize podle svých kritiků přispívá k přeměně fanouška na konzumenta, způsobuje erozi základen fanoušků menších klubů, prohlubuje nerovnosti mezi kluby a napomáhá koncentraci bohatství a úspěchu. Vlastní televizní kanály největších klubů deformují princip kolektivního prodeje televizních práv. Pod vlivem zájmu televizních společností se v některých zemích objevuje trend k „odstraňování nejistoty výsledku“ a oslabování domácích soupeřů díky různým kartelovým dohodám. Přesun fotbalu na placené kanály ohrožuje možnost všeobecného přístupu k jeho sledování, exkluzivita placených přenosů ohrožuje národně-integrační funkce a představuje útok na kulturní práva většiny, přesto však např. ve Velké Británii všechny hlavní politické strany preferují deregulaci [Giulianotti 1999: 95-97]. Některé studie rovněž prokazují sníženou návštěvnost utkání vysílaných v přímém televizním přenosu [např. Allan - Roy 2008].

Přeměna fotbalu na zboží distribuované k zákazníkům prostřednictvím televize má za následek komplexní kvalitativní proměnu prostředí, ve kterém se jednotlivá utkání odehrávají. Komerční zájmy velkých klubů, směřující k získání co možná nejširšího publika, vyžadují všeobecnou přijatelnost nabízeného produktu, což předpokládá eliminaci předem daných sociálních a kulturních významů. Krajina fotbalových klubů, včetně

hráčem na britském trhu s televizními právy. Tuto společnost, která poskytuje placené satelitní vysílání, de facto kontroluje mediální magnát Rupert Murdoch, jehož News Corporation vlastní v BSkyB čtyřicetiprocentní podíl [Giulianotti 1999: 91].

8 Jde o Paris Saint Germain (Canal Plus, ale pouze dočasně) a AC Milán (Mediaset). V případě milánského týmu je střet zájmů fotbalového klubu a televizní společnosti multiplikován politickou kariérou majitele Mediasetu Silvia Berlusconiho. Některé mediální korporace nicméně odradil od podobných snah neúspěch BSkyB při pokusu o koupi Manchesteru United z roku 1998. Cílem této transakce bylo z pohledu BSkyB zajištění dlouhodobé dominantní pozice na britském satelitním trhu a zejména na nově vznikajícím digitálním trhu. Zpočátku se sice zdálo, že by obchod mohl být úspěšný, po několika měsících se však mezi experty i fanoušky zvedla mohutná vlna odporu. V čele kampaně stála fanouškovská iniciativa Shareholders Against Murdoch. V důsledku nesouhlasu veřejnosti britská vláda předala celou kauzu Monopolies and Merger Commission, která transakci zakázala s odůvodněním, že narušení soutěže na mediálním trhu je v rozporu s veřejnými zájmy a že následné prohloubení nerovnosti mezi kluby by vedlo k poklesu kvality anglického fotbalu. Konečný verdikt komise byl v té části tisku, která nepatřila Murdochovi, přijat až na výjimky velmi kladně [Robertson 2004: 306-307; Ross 2004: 89]. 
špičkových, vzájemně podobných stadionů, se přetváří na spotřebitelsky orientovaný individualizovaný prostor. Jádro této změny tkví ve standardizaci a hyperrealizaci fotbalu a v aplikaci formálně racionálních principů moderní průmyslové výroby [Sandvoss 2003: 166]. Současný televizní sport (a tedy i fotbal) podléhá dvoustupňové konstrukci, nejprve na stadionu, a pak při televizním zpracování [Bourdieu 2002: 91]. Televize tak fotbal spíše simuluje a hyperrealizuje, než aby ho reprezentovala. Pasivní sledování televize vede $\mathrm{k}$ převaze obrazu nad participací, informací nad zážitkem, bezmístné univerzálnosti nad lokální zakotveností, bezobsažnosti nad významem [Sandvoss 2003: 166-167].

\section{Sponzorství a merchandising}

Díky značnému mediálnímu prostoru, vysoké sledovanosti a společenské prestiži se fotbal stal prostředkem sebeprezentace zejména velkých firem nejrůznějšího zaměření. Tato forma komerčního využití fotbalu se projevuje různými způsoby, zejména však sponzorstvím vrcholných akcí (oficiální partneři) či klubů (jména sponzorů a firemní loga na dresech, reklamních panelech na stadionu, jména stadionů, klubů, či soutěží apod.), nebo naopak účinkováním fotbalistů v reklamách. Ve Spojeném království se logo sponzora objevilo poprvé na dresu FC Liverpool v roce 1978 [Howard - Sayce 2002: 3], dnes je však komodifikace dresu zcela běžnou záležitostí, nebot jméno hlavního sponzora mají na dresu všechny velké kluby s výjimkou FC Barcelona, pro niž jsou klubové barvy příliš posvátné. Atraktivita sponzorství a možnosti sebeprezentace na dresech především největších klubů v současnosti roste, protože inzerce do stále více fragmentarizovaných tradičních médií (noviny, rozhlas, rostoucí počet televizních kanálů, internet) je méně efektivní. Větší globální viditelnost velkých klubů zvyšuje rozdíly v cenách za umístění sponzorského loga na dres a prohlubuje tak meziklubové nerovnosti [Price Takers rather than Price Makers 2009]. ${ }^{9}$

Zcela strategický význam má sponzoring sportovních akcí a týmů pro výrobce značkového sportovního oblečení, kteří ve snaze zvýšit pravděpodobnost své podpory vítězného týmu (a získání prestižního hesla pro své reklamní kampaně) sponzorují více týmů. Někteří autoři proto s trochou nadsázky hovoří o mistrovství světa jako o souboji Nike a Adidas. Často však nastává konflikt mezi smlouvami týmů a jednotlivých hráčů, které ovlivňují mimo jiné přestupy hráčů. ${ }^{10}$ Součástí firemních strategií o získání vyššího

9 Zatímco klub typu Bolton Wanderers získá ročně touto cestou přibližně 0,75 milionu liber, FC Liverpool v roce 2009 uzavřel s bankou Standard Chartered čtyřletou smlouvu o celkovém úhrnu 80 milionů liber. Předchozí smlouva s pivovarem Carlsberg mu zaručovala roční př́ijem 7,2 milionu liber [Price Takers rather than Price Makers 2009; 'Pool Do the Deal 2009]. Míru komodifikace fotbalových dresů a moci soukromých korporací uvnitř fotbalu lze symbolicky demonstrovat na př́kladu kauzy z března roku 1997. Útočník FC Liverpool Robbie Fowler si při oslavě svého druhého vstřeleného gólu v zápase proti norskému týmu Brann Bergen vyhrnul dres a čelem k divákům ukázal tričko s nápisem: „Od roku 1995 dostalo padáka 500 liverpoolských dokařů.“ Tito dokaři stávkovali proti stovkám nucených odstávek a upřednostňování práce na krátké pracovní úvazky. Vedení FC Liverpoo Fowlerovo jednání odsoudilo, dostal od UEFA pokutu 2000 švýcarských franků a napomenutí, že pro příště prostor na dresech patřil výhradně logům sponzorů. Písmena c a k ve slově dockers navíc svým vizuálním provedením připomínala logo společnosti Calvin \& Klein, která dokonce zvažovala žalobu za poškozování práv k obchodní známce poté, co fotografii s dotyčným tričkem otiskly všechny britské noviny [Kleinová 2005: 188-189].

10 Př́kladů lze uvést mnoho. Brazilský útočník Ronaldo uzavřel s firmou Nike smlouvu na minimální roční př́ijem ve výši deset milionů liber po dobu deseti let a údajně dalších 120 milionů liber v průběhu života po skončení fotbalové kariéry. Díky tomu se dostal do konfliktu se svým zaměstnavatelem 
podílu na trhu je rovněž ovlivňování organizace přátelských zápasů, takže FIFA založila vlastní pracovní skupinu, která se tímto fenoménem zabývá [Hare 1999]. Na druhé straně firmy typu Nike mohou díky své dominantní pozici na trhu napomoci v boji proti rasismu a prostřednictvím své reklamní kampaně včlenit antirasistické prvky do konzumní kultury. Hlavním cílem Nike nicméně zůstává budování image značky a dosahování zisku, takže tato snaha má omezenou, nepolitickou formu a netýká se jiných forem nerovností [Miller - van Zoonen - de Roode 2008].

Jak bylo naznačeno $\mathrm{v}$ předchozím textu, existuje zde několik vzájemně se posilujících faktorů, které způsobují rostoucí nerovnost mezi fotbalovými kluby: deregulace trhu s televizními právy, vstup na burzu, deregulace fotbalového pracovního trhu a v obecnějším smyslu povaha ekonomické a kulturní globalizace. Nejbohatší kluby v devadesátých letech začaly přejímat strategie velkých firem a snaží se své popularity využít k vytvoření globální značky, musí však čelit riziku rozpadu stabilní fanouškovské základny, jejíž udržení je conditio sine qua non obchodního úspěchu. Marketinkové strategie směřující k přeměně fanouška na zákazníka a k prodeji nejrůznějšího, značně diverzifikovaného zboží s oficiální klubovou symbolikou, nazvané merchandising, byly nejvíce rozpracovány v Anglii. Jako př́klad lze uvést Manchester United, jeden z nejbohatších světových klubů, kterému nejširší základna fanoušků přináší nejvyšší př́ijmy z merchandisingu, prodeje rozmanitých produktů s logem klubu v mnoha zemích světa. Vedení klubu má nicméně ve vztahu k fanouškům monopolní pozici: na jedné straně vlastní výhradní práva na prodej tohoto typu zboží, na druhé straně si je vědomo skutečnosti, že fanoušek Manchesteru United si díky své emocionální oddanosti vůči klubu nepůjde koupit dres konkurenčního klubu jen proto, že je o několik liber levnější. Této skutečnosti klub často využívá, např. poměrně vysokou frekvencí designových změn dresů, a má proto pověst bezohledného vykořistovatele fanouškovské základny [Brick 2004: 103-104]. Ačkoli je bohatství Manchesteru United z velké části zásluhou fanoušků (prodej suvenýrů, vstupné, placená televize), vztah mezi nimi a vedením klubu je kvưli jeho př́lišné orientaci na zisk a neochotě vést dialog s fanoušky poněkud odcizený [Lee 1998: 37].

\section{Proměny identit klubových fanoušků}

Sdružování fanoušků kolem fotbalových klubů se stalo pro mnoho lidí významným zdrojem identity a sociálních vazeb, podoba jejich vztahu ke klubu i k sobě navzájem se projevuje v různých formách, lišících se v čase a prostoru. Pozitivní („kdo jsme?“) i negativní („kdo nejsme?“) identity jednotlivých skupin fanoušků se utváří vždy na základě konkrétní společensko-historické situovanosti klubu a v praxi se v nich různým způsobem kombinují vlivy příslušnosti k městské části, městu (či obci), regionu, státu, rase, etnicitě, národu, náboženství, tř́ídě i politickému proudu.

Podle Escobara pomáhalo zakládání fotbalových klubů a svobodné a dobrovolné sdružování hráčů a fanoušků, často podporované ze strany klubů, k integraci izolovaných

FC Barcelona (sponzorovaná firmou Kappa) a plánovaným budoucím zaměstnavatelem Laziem Řím (sponzor Umbro). Ronaldo nakonec přestoupil do Interu Milán, který podepsal smlouvu s Nike a během deseti dnů po přestupu prodal 35 tisíc replik dresů s jeho jménem. Otázka, zda hráče „vlastní“ Inter nebo Nike zůstala nezodpovězena. Podle některých brazilských reprezentantů se za účastí nedoléčeného Ronalda ve finále Mistrovství světa 1998 skrývá tajná dohoda mezi Nike a brazilskou fotbalovou federací [Giulianotti 1999: 89-90]. 
a odcizených obyvatel do větších celků uvnitř rychle rostoucích měst (i za jejich hranicemi) v období industrializace, k rozvoji hlubších forem solidarity a sdílené identity [Escobar in Giulianotti 1999: 15]. Pevné vazby klubů (včetně hráčů) na místo a komunitu jsou v průběhu modernizace podemílány mimo jiné mobilitou hráčů a rozš́řrením, ale i destabilizací fanouškovské základny [Giulianotti 1999: 15].

Pestrost a proměnlivost podob a projevů identity fotbalových fanoušků se stala častým tématem výzkumné práce nejen v sociologii fotbalu, ale i historii, antropologii či marketinku. Na základě různorodých prrístupů ke studiu fotbalových identit byla vytvořena řada teoretických zobecnění, reflektujících odlišné společenské souvislosti, a umožňujících tak nahlížet na tento fenomén v rámci rozdílných, vzájemně se doplňujících perspektivách.

Richard Giulianotti a Gary Armstrong rozlišují sedm druhů identitních opozic, z nichž nejvýznamnější je konstrukce konfliktních identit, odrážejících i aktivně utvářejících mocenské nerovnosti v rámci sociální struktury. Konfliktní identita se vyskytuje ve třech různých variantách, které se mohou v čase proměňovat. Legitimizační identita je konstruována skrze dominantní společenské instituce a přispívá tak k reprodukci (eventuálně i změně) existujících mocenských vztahů a občanské společnosti (např. existence národních svazů přispívá k rozvoji národního vědomí, dominantní klub reprezentující hodnoty vládnoucí skupiny podporuje udržení její pozice, např. Juventus Turín v Itálii). Rezistenční identity konstruují mocensky marginalizované skupiny, které si takto vytváří možnost kolektivní komunitní obrany (např. fanoušci Millwallu). Projektovou identitu vytváří ti, kteří hledají alternativu a usilují o transformaci (např. hnutí nezávislých příznivců, či emancipační hnutí Katalánců spjaté s FC Barcelona) [Giulianotti - Armstrong 2001: 270]..$^{11}$

Existence vyhrocených vzájemných rivalit mezi jednotlivými týmy se však podstatně méně vyskytuje ve východoasijských zemích, kde jejich rozvoji brání kolektivistická a na dosažení harmonie orientovaná konfuciánská kultura. Západní nacionalismus,

11 Jako příklad lze uvést nejpopulárnější chorvatský klub Dinamo Záhřeb, který symbolizoval „rezistenční“ národní chorvatskou identitu, která stála v opozici vůči národní jugoslávské identitě, podporované dominantním srbským etnikem. Na počátku devadesátých let identifikace s Dinamem získávala stále více „projektový“ charakter a po osamostatnění Chorvatska díky podpoře nacionalismu i charakter „legitimizační“ ve vztahu k novému chorvatskému státu. Součástí této role byla i změna názvu na Croatia Záhřeb, podporovaná vládou i prezidentem Tudjmanem, která ale vyvolala odpor u skupiny fanoušků zvané Bad Blue Boys a později i např́č celým Chorvatskem. Tyto skupiny byly nejprve veřejně napadány a exkludovány, díky opětovnému posunu směrem k „projektové identitě“ a postupnému oslabení vyhraněného nacionalismu se po nátlaku fanoušků název klubu změnil zpět na Dinamo.

Mezi dalších šest druhů identitních opozic patří dramatizace mocenských vztahů (skutečná nebo vnímaná dominance jednoho klubu - např. Juventus Turín, Manchester United, Glasgow Rangers - vede příznivce ostatních vymezení se vůči němu), „potopená národnost“ (identita klubu vázaná na menšinovou či skrytou národnost, např. baskický Athletic Bilbao), minoritní identita a lokální rozdíly (např̀. Aberdeen jako protiklad tradičních rivalů z Glasgowa - protestantských Rangers a katolického Celti$\mathrm{cu}$ ), symbolické násilí exkluze ( $\mathrm{v}$ případech neobvykle silného rozdělení společnosti dochází k marginalizaci některých skupin, což bývá někdy doprovázeno projevy fyzického násilí, např. Millwall), estetické kódy (střet mezi tradičním a moderním herním stylem, např. Argentina) a transformace rivalit v dezorganizovaném kapitalismu (budování nových projektů globálních „značkových“ identit velkých klubů, neumožňujících vznik komunit pro lokální fanoušky, přispívá k destabilizaci starých legitimizačních identit; hierarchická struktura fotbalu je v podmínkách růstu vlivu nadnárodních mediálních a sportovních korporací zpochybňována střety mezi G14 a UEFA, mezi kluby a národními svazy) [Giulianotti - Armstrong 2001: 272-278]. 
kompetitivní individualismus a v minulosti otevřený imperialismus a výraznější latinský rodinný či obecní šovinismus vytváří pro rozvoj rivalit příznivější podmínky [Giulianotti 1999: 14].

Povaha vztahu fanoušků ke „svému“ klubu se stala ústředním motivem typologie opět Richarda Giulianottiho [2002] a také Lloyda Harrise a Emmanuela Ogbonny [2008]. Giulianotti nahlíží na vztah fanoušků ke klubu z hlediska zásadní kvalitativní přeměny, kterou prodělal $v$ důsledku komercializace fotbalu a proměny forem sociability $\mathrm{v}$ průběhu modernizačních procesů. Na základě dvou binárních opozic, znázorněných dvěma vzájemně kolmými osami, rozlišuje čtyři odlišné ideálně-typické druhy fanoušků. První osa vyjadřuje protiklad mezi tradicí (delší, loajálnější, lidová identifikace s klubem) a konzumerismem (více tržně orientovaný vztah ke klubu, zaměřený na konzumaci klubových produktů), druhá odráží na škále vášnivý/chladný stupeň důležitosti klubu pro sebeformování individua. Kombinací těchto dvou os získáme čtyři kvadranty, každý reprezentuje jeden typ divácké identity. Schéma č. 1 níže představuje základní charakteristiku jednotlivých typů: supporter (tradiční/vášnivý), follower (tradiční/chladný), fan (konzumní/vášnivý) a flâneur (konzumní/chladný). ${ }^{12}$

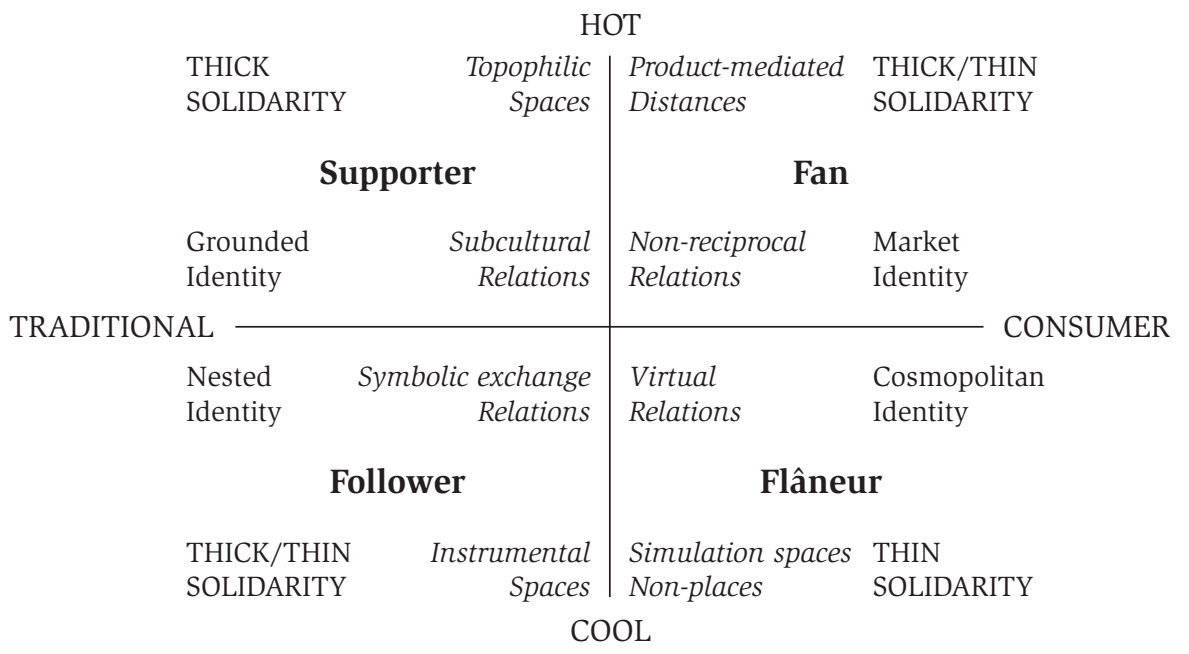

Schéma č. 1: Typologie identit fotbalových diváků Richarda Giulianottiho

Zdroje: převzato z Giulianotti, Richard. [2002]. Supporters, Followers, Fans, and Flaneurs: A Taxonomy of Spectator Identities in Football. Journal of Sport and Social Issues 26 (November 2002), No. 2, s. 31.

Základní trendy v proměně fotbalového fandění spočívají v úpadku tradic, vzestupu konzumu, oslabování významu oblíbeného klubu pro jedince (a naopak růstu pravděpodobnosti jeho změny), solidarity s klubem, s ostatními fanoušky i s místem síd-

12 V textu i schématu ponechávám původní anglické termíny, nebơ čeština nedisponuje dostatkem významově odlišitelných a zároveň odpovídajících výrazů. Ve většině anglofonní literatury se navíc obvykle používají jen výrazy supporter a fan, chápané jako synonyma. 
la klubu; jinými slovy - ústup supporters provází vzestup flâneurs, ostatní kategorie jsou únikové varianty, jakési mezistupně uvnitř hlavních tendencí. Supporter a flâneur představují sice protikladné kategorie, na druhé straně jsou ale na sobě závislí. Supporter uznává, že v neoliberálním prostř̌edí je třeba v zájmu úspěchu a přežití přilákat konzumenty, flâneur se od něj však distancuje. Pokud se ale ze všech supporters stanou flâneurs, bude celý spektákl ohrožen, nebudou zde projevy tribalismu minulosti a „kosmopolitní“ flâneurs ztratí objekt pozorování a možná i zdroj významů pro konstrukci vlastní identity [Giulianotti 2002].

Harris a Ogbonna se namísto rozboru vývojových trendů pokoušejí vztah mezi fanouškem a klubem (z pohledu psychologie fanouška) podrobněji operacionalizovat. Ačkoli všichni fanoušci věří, že mají ke svému klubu emocionální vztah, je možné rozlišit čtyři roviny tohoto vztahu, které nemusí být vždy přítomné všechny u každého fanouška: intimita, interakce, důvěra, oddanost. Na základě př́tomnosti a míry intenzity jednotlivých dimenzí autoři identifikují sedm kategorií fanoušků: armchair supporters, social fans, oldtimers, leisure switchers, antifans, club-connected supporters a die-hard fanatics. Identifikace a emocionální vztah fanoušků se týkají především klubu jako sportovního týmu (hráčů, trenéra atd.) a kulturního elementu (historie klubu, tradic, hodnot), nikoli organizace a managementu. Řada fanoušků tak odmítá firemní strategie mnohých klubových vedení na budování vzájemného vztahu [Harris - Ogbonna 2008].

$\mathrm{V}$ souladu s proměnou procesu socializace a s Baumanovou tezí o nakupování vlastní identity se merchandising stává stále významnější položkou v př́ijmech velkých klubů (zejména v Anglii), vlastnictví předmětů s logem klubu plní pro mnohé fanoušky důležité symbolické funkce identifikace, integrace, exprese a sakralizace [Derbaix Decrop - Cabossart 2002: 511]. Tradiční fanoušci sice komercializaci přijímají jako nutnost, často jim ale vadí vnímání fanoušků jako zákazníků (hraničící v některých př́padech s vykořistováním ze strany vedení klubů). Vzhledem k orientaci vedení klubů na movitější skupiny může být navíc ohrožena socializace nové generace aktivních fanoušků [Giulianotti 2005: 406].

Značkové strategie největších klubů zaměřené na přeměnu fanoušků v konzumenty mohou úspěšně realizovat pouze větší kluby s dostatkem finančních zdrojů a s dostatečně specifickou identitou pro fanoušky z celé země. Joke Oppenhuisen a Liesbet Van Zoonen na př́kladu nizozemských klubů ukazují, že příznivci velkých klubů asociují své týmy s hodnotami tradice a úspěchu, zatímco fanoušci menších regionálních klubů spojují své týmy s hodnotami sociálních vztahů a volného času. Rozmach značkových strategií v praxi vede $\mathrm{k}$ růstu ekonomických nerovností mezi kluby [Oppenhuisen - van Zoonen 2006: 70-71].

Podle Cornela Sandvosse je fandění založeno na sérii spotřebních praktik, zároveň však slouží ke komunikaci fanoušků. Kluby je možné chápat jako prostor sebereflexe pro fanoušky a většinou neuvědomované prodloužení a projekci sebe sama do klubu („vyhráli/prohráli jsme“). V současnosti dochází k růstu diverzity znaků umožňujících fanouškům sebevyjádření, tato volba je však ve skutečnosti zmenšována racionalizačním imperativem tvořícím základ konzumního systému. Rozšíření fanoušků klubů (např. Chelsea) daleko od tradičního sídla, kde nemají prostředky na sledování svého týmu př́mo na stadionu, ukazuje, jak racionalizovaný konzum eliminuje volby, které sám produkuje [Sandvoss 2003: 44, 102]. 
V souvislostí postupující kulturní a ekonomické globalizací, rozmachu elektronických médií, rostoucí horizontální mobilitě a narušení tradičních komunitních vazeb dochází ke glokalizaci (nejen) fotbalových identit, střetávání univerzalizujících symbolů $\mathrm{s}$ lokálním prostředím. Identifikace fanoušků s největšími kluby již v řadě př́padů není závislá na prostorové blízkosti. Vzhledem k rozmachu médií lze ve vzdálených zemích sledovat utkání vybraných evropských klubových soutěží (zvláště Ligy mistrů a Premier League). Na druhé straně skutečnost, že se fanoušci v těchto zemích identifikují se vzdálenými velkokluby, svědčí o úpadku lokálních vazeb, individualizaci a kosmopolitizaci společnosti (nebo aspoň některých skupin), rostoucí globální provázanosti a vlivu dominantního centra na periferní oblasti. Jako př́klad lze uvést početnou skupinu izraelských fanoušků anglických klubů, která je složena převážně ze vzdělaných příslušníků nové střední tř́́dy [Ben-Porat 2000: 349]. Na druhé straně existují početné skupiny emigrantů, které (opět v důsledku rozvoje elektronických médií) udržují mimo jiné díky fotbalu pocit blízkosti a identifikace se starými kulturními institucemi [např. Giulianotti - Robertson 2007: 148].

Identita fanouška a jeho vztah k oblíbenému klubu v éře komercializovaného fotbalu nabývá rozmanitých forem, vedle tradičních podob fandovství zde existují fragmentarizované, spotřebně orientované, méně stálé a z lokálních komunit vyvázané způsoby indetifikace. Přizpůsobení fotbalu tržní logice orientované na dosahování zisku oslabuje tradiční významy i komunitární formy fandění, vrcholový fotbal se tak více univerzalizuje a unifikuje a (zvláště na klubové úrovni) dochází k oslabení jeho politické role. Vliv komercializace na postupnou depolitizaci fotbalu dokládají studie z řady zemí [napr̆. Yarar 2005; Ben-Porat 1998; Lee 1998]. ${ }^{13}$

\section{Vývoj a šíření profesionalismu}

Jedním z klíčových aspektů komercializace fotbalu byla jeho profesionalizace, tzn. přeměna fotbalu z volnočasové aktivity na placené zaměstnání, která byla možná pouze v moderní společnosti, kde byla $\mathrm{v}$ rámci procesu generalizace trhu lidská práce přeměněna na zboží. Tento přerod se uskutečnil v Anglii v první polovině 19. století a z části se časově překrýval s obdobím vzniku moderního fotbalu. Není tedy nikterak překvapivé, že se profesionalismus poprvé objevil v Anglii o několik desetiletí později, jakkoli se lze s finančními odměnami za sportovní výkony v rané podobě setkat již v dřívějších letech.

Kolébka profesionálního fotbalu se nachází v hrabství Lancashire, kde v průběhu sedmdesátých let vznikla řada profesionálních klubů, které vydělávaly na vybírání vstup-

13 Jako př́klad lze uvést situaci anglických fanoušků v éře Margaret Thatcherové, která byla charakteristická důrazem na pořádek v souvislosti s řešením otázky fotbalových chuligánů a neoliberálními ekonomickými reformami, které podpořily nastoupený trend komercializace fotbalu. Simon Lee ve své charakteristice ukazuje, že fotbalové fandění nebyla jen otázka trávení volného času, ale bylo nedílnou součástí sociability a kultury dělnické tř́ídy a její narušení tak významně ovlivnilo každodenní život fanoušků a ve svých důsledcích mělo politickou povahu: „Komercializace anglického fotbalu, přinejmenším na úrovni Premier League, vylepšila i umrtvila prožitek fotbalových fanoušků. Tento především emocionální zážitek, který nemůže být redukován na úroveň individuální spotřeby nebo na tržní transakci, dlouho poskytoval lidem žijícím v Anglii důležitý zdroj kolektivní (často občanské) identity a hrdosti. Později pro mnohé sloužil jako stěžejní zdroj komunity, identity a útočiště před sobeckými a materialistickými hodnotami thatcherismu, usilujícího o odstranění mnoha dalších prostředků, pomocí nichž by si Angličané mohli sami sebe představit jako něco víc než jen sumu stále izolovanějších individuí [Lee 1998: 48].“ 
ného a dávaly hráčům (často ze Skotska) finanční odměny. The Football Association (FA) na tuto situaci reagovala zákazem profesionálního fotbalu v roce 1882, což vedlo k sérii vzájemných obvinění mezi jednotlivými kluby z porušování tohoto ustanovení a počátkem bojů mezi zastánci profesionalismu, převládající na průmyslovém severu Anglie s vyhraněnější třídní strukturou, a stoupenci amatérismu, převažujícími na jihu Anglie (zvláště v Londýně). Restriktivní politika FA nakonec vedla k návrhu na založení vlastní nezávislé soutěže, který předložilo několik severních klubů, takže byl v roce 1885 profesionalismus ve značně regulované podobě povolen. $\mathrm{V}$ dalších letech proto získaly převahu profesionalizované severní kluby, které byly často financované z peněz majitelů továren, a mohly tak vytvářet speciální týdenní tréninkové tábory. Riziko předčasného vyřazení v FA Cupu vedlo profesionalizované kluby v roce 1888 k založení pravidelné soutěže s vlastní organizací (Football League).

Legalizací profesionalismu si FA chtěla udržet kontrolu nad fotbalem. Přistoupila proto k sérii regulačních opatření, jako byl systém odstupného a maximální výše platu, smlouvy maximálně na jeden rok či povinné registrace hráčů na svazu [Brändle - Koller 2002: 72-74]. Hráči nesměli opustit klub po skončení smlouvy bez souhlasu zaměstnavatele a byli povinni nezávisle na své vưli akceptovat změnu působiště, kdykoli se tak rozhodl jejich původní zaměstnavatel. Profesionalizace sice vedla ke zvýšení mezd, pohybujících se na úrovni odměn kvalifikovaných dělníků, ale hráči byli podrobeni disciplíně srovnatelné s armádou. Pracovně-právní postavení fotbalistů tak v této době mělo „kvazifeudální“ charakter [Hargreaves 1987: 69-70].

Tato situace přiměla hráče $v$ roce 1899 k založení prvních fotbalových odborů a o osm let později díky hráčům Manchesteru United k založení Professional Footballer’s Association (PFA), která požadovala především zrušení maximální hranice mezd a nemožnosti vlastní volby pracovního místa. PFA se přičlenila ke General Federation of Trade Unions (GFTU), čímž dala najevo, že pokládá fotbal za průmyslové odvětví a fotbalisty za dělníky. FA zareagovala realizací rázných protiopatření, aby narušila jednotnost odborového hnutí a eliminovala možnost solidárních stávek s dělníky z jiných průmyslových odvětví [Brändle - Koller 2002: 75-76]. Ačkoli byla organizovanost v odborech v některých obdobích relativně vysoká, byla PFA vždy převážně pasivní, konformní a nekonfliktní organizací, která spíše než k prosazování kolektivního vyjednávání přispívala k rozvoji nerovností mezi jednotlivými hráči [Hargreaves 1987: 128]. V Anglii, ale i v řadě dalších evropských zemí, je proto třídní vědomí fotbalistů rozvinuto podstatně méně, než např. v Latinské Americe, kde hráči př́ležitostně vstupují do stávek, které v některých př́ípadech trvají několik let [Giulianotti 1999: 113]. Zlomový moment nastal v roce 1961, kdy PFA úspěšně zažalovala zaměstnavatele sdružené ve Football League a vynutila si zrušení maximální výše platu a o dva roky později změnu přestupního řádu. Hráčské mzdy se tak postupně začaly vzdalovat dřívějšímu maximu 20 liber týdně a docházelo také mimo jiné i ke zvyšování přestupových částek a vstupného na zápasy [Hargreaves 1987: 115].

Trend profesionalizace fotbalu se ve většině evropských zemí projevil později (v meziválečném období, ${ }^{14}$ po druhé světové válce, nebo až po pádu režimů komunis-

14 Otázka profesionalismu ve fotbale ovlivnila i formování mezinárodních sportovních organizací. V roce 1927 vznikl spor mezi Mezinárodní fotbalovou federací (FIFA) a Mezinárodním olympijským výborem (MOV) o to, kdo bude rozhodovat o organizaci fotbalu na olympijských hrách. FIFA nakonec 
tických stran) a mnohdy byl poznamenán vývojovými diskontinuitami, jejichž kořeny je nutné hledat mimo fotbal. V Německu byl po sérii konfliktů klubů s Deutsche FussballBund (DFB) profesionalismus na konci roku 1932 povolen, Hitler jej však krátce po svém nástupu zakázal. $\mathrm{K}$ jeho opětovnému povolení došlo $\mathrm{v}$ silně regulované podobě v roce 1960 v důsledku neúspěchů klubů a odchodu reprezentantů do zahraničí a deregulace (včetně zrušení maximální výše platu) byla provedena až v roce 1974. V Rakousku, Československu či Mađ’arsku byl profesionalismus zaveden v meziválečném období, ale $\mathrm{v}$ důsledku anšlusu či německé okupace a případně později zavedení státního socialismu byl tento vývoj dočasně přerušen [Brändle - Koller 2002: 86-95]. Vrcholoví fotbalisté v socialistických zemích, formálně evidovaní jako zaměstnanci průmyslových podniků, dolů či armády, které zastřešovaly velkou část klubů, se však v praxi často mohli plně věnovat pouze sportu, a měli tak de facto profesionální podmínky pro vlastní prrípravu. Výše jejich př́ijmu, vypláceného státem, však byla pevně stanovena, což platilo i pro období perestrojky, kdy došlo v Československu k povolení regulované formy profesionalismu [Duke 1990: 151-154]. Deregulace fotbalového pracovního trhu nastala až po pádu socialismu a byla provázena nárůstem mobility hráčů (i do zahraničí), nárůstem jejich př́ijmů i přestupových sum.

Mimo Evropu byl profesionalismus zaveden poprvé ve třicátých letech v některých zemích Jižní Ameriky, např. Argentině a Brazílii [Bedřich 2006: 32-33]. V Brazílii začaly hrát fotbal nejprve vyšší vrstvy v Rio de Janeiru a v Sao Paulu na počátku 20. století, které se jej naučily od Angličanů. Fotbal se tehdy stal elitní zábavou a symbolem exkluze, přístup do klubů byl určován socioekonomickým postavením a v menší míře i rasou. K rozšíření fotbalu mezi širší vrstvy obyvatel přispěl rozmach průmyslu za 1 . světové války a s ním související výroba míčů i využití fotbalu jako nástroje pacifikace dělníků. Průvodním jevem šíření fotbalu byl odpor elit k př́itomnosti hráčů černé barvy pleti na hřršti, který se výrazněji prolomil až ve třicátých letech v souvislosti se snahou o lepší mezinárodní výsledky. Obava bílých elit o ztrátu hegemonie ve prospěch černých hráčů či dělníků stála i v pozadí odporu k profesionalismu. Jeho zavedení v roce 1933 se stalo pro menšinu hráčủ potenciálním mobilitním kanálem, většina ostatních však dostávala velmi nízké mzdy. Vznik rasově smíšených týmů přispěl k pozitivnějšímu vnímání míšenectví v brazilské populaci, přetrvávající nerovnosti však způsobují v některých případech silně třídně podmíněné identifikace s lokálními kluby [Daflon - Ballve 2004]. Právě v Jižní Americe a v Evropě, kde jsou největší fotbalové trhy, hrají tři čtvrtiny všech profesionálních fotbalistů [Horne - Manzenreiter 2004: 2].

Naproti tomu v Asii byla první profesionální (pro fotbal netypicky uzavřená a soukromá) soutěž založena v roce 1983 v Jižní Koreji [Ravenel - Durand 2004: 25]. Zcela odlišným zpo̊sobem ve srovnání s Evropou byla vytvořena profesionální liga (Japan League) v Japonsku. Místní fotbalový svaz se rozhodl řešit krizi domácí ligy a zaostávání za ostatními zeměmi (zvláště za Jižní Koreou) na přelomu osmdesátých a de-

rozhodla, že je nejvyšší autoritou ve všech fotbalových zápasech a tudíž není povinna přijímat zásahy zvenčí. Dále uznala svrchovanost International Football Association Board (IFAB) ve věci rozhodování o změnách pravidel, zavedla (od roku 1930, s výjimkou let 1942 a 1946) pravidelné mistrovství světa (World Cup) nezávislé na olympijských hrách a po dohodě s MOV uznala nárok amatérských fotbalistů na kompenzaci za čas strávený na OH. Toto opatření, vnímané jako falešný amatérismus, přimělo všechny čtyři britské asociace po čtyřletém členství k vystoupení z FIFA, kam se navrátily až po druhé světové válce [Pickford 1940-1941: 85-92]. 
vadesátých let ve stylu reforem Meidži: nejprve byly hledány alternativy, poté probíhalo důkladné studium různých způsobů komercializace sportovních soutěží v Evropě a v Severní Americe a na závěr došlo na aplikaci optimálního řešení pro japonskou situaci. Vhodným omezením komerčních aspektů a spolupořádáním mistrovství světa (2002) se podařilo $\mathrm{v}$ podstatě $\mathrm{z}$ ničeho vytvořit desítky milionů přinejmenším pasivních příznivců a potenciálních zákazníků a dosáhnout komerčního úspěchu [Ichirō 2004: 51-53]. Profesionalizovaná (a komercializovaná) ligová soutěž byla vytvořena roku 1994 dokonce i v Číně, kde se fotbal začal dynamičtěji rozvíjet až v období reforem Teng Siao Pchinga [Jones 2004: 57].

Dalším klíčovým mezníkem ve vývoji fotbalového profesionalismu v Evropě, který měl ale přímé dopady i na okolní svět, se stala kauza Bosman. ${ }^{15}$ Po vynesení rozsudku proběhl krátkodobý experiment se zcela deregulovaným fotbalem. Již po dvou letech ale byla v Deklaraci o sportu v rámci Amsterdamské smlouvy uznána specifičnost sportu a v dalších letech bylo stanoveno, že sportovní organizace včetně Evropské fotbalové unie (UEFA) jsou zcela autonomní v rozhodování o sportovních otázkách, ale v komerčních záležitostech podléhají regulaci ze strany evropského práva. Tento př́stup EU a členských zemí UEFA je odrazem specificky evropského pojetí sportu [Foster 2005: 80-81] . ${ }^{16}$ Kauza Bosman měla řadu závažných důsledků, kromě zlepšení vyjednávací pozice hráčů šlo především o obrovský nárůst mobility hráčů (především v Evropě), přesun rovnováhy směrem $\mathrm{k}$ nejbohatším klubům disponujícím v podstatě neomezeným přístupem k nejlepším profesionálním hráčům (jen bohaté kluby si mohou dovolit vynakládat rostoucí sumy za přestupy nejlepších hráčů) a masivní nárůst platů nejlepších hráčů a s tím související zvyšování výdajů na platy hráčů (viz Tabulka 2). Mezi možná řešení hrozící (nebo již existující) finanční krize klubů bývá někdy řazeno opětovné zavedení platových stropů, či přerozdělování části příjmů mezi kluby (o finanční krizi evropských klubů podrobněji níže). Míra dopadu kauzy Bosman na jednotlivé země je různá, v některých zemích např. došlo k úpadku mládežnických týmů [Giulianotti 1999: 122].

15 Jean-Marc Bosman byl průměrný hráč prvoligového belgického klubu RC Liège, kterému v červnu 1990 vypršel kontrakt. Byla mu nabídnuta nová smlouva s platem nižším o 75 \%, odpovídajícím minimu stanovenému belgickým svazem. Bosman nabídku odmítl a kontaktoval francouzský druholigový klub US Dunkerque, který souhlasil s přestupem nebo s hostováním. Liège však mělo pochybnosti o finanční situaci Dunkerque, zrušilo dohodu a hráči pozastavilo činnost. Bosman se obrátil k soudu a požadoval měsíční plat od Liège a odstranění poplatku za přestup, když si sháněl nový klub. Belgický soud předal celý případ k Evropskému soudu. Bosman zde předložil argument, že regulace přestupů odporují článku 48 Římské smlouvy, který zaručuje volnost pohybu pracovních sil po území Evropské unie bez národnostní diskriminace. Soud rozhodl v jeho prospěch a prohlásil pravidlo o regulaci počtu cizinců nastupujících v klubových zápasech za ilegální. UEFA tak musela zrušit veškerou regulaci přestupů v rámci Evropské unie. Hráči, kterým skončila smlouva, byli od nynějška volní [Giulianotti 1999: 121-122].

16 Tento postoj nicméně zastává Evropský soudní dvůr již od sedmdesátých let, viz př́pad Walrave a Koch v. Association Union Cycliste Internationale z roku 1974. Ve fotbale se nicméně začal uplatňovat až po kauze Bosman [Judgment of the Court of 12 December 1974. B. N. O. Walrave and L. J. N. Koch v Association Union Cycliste Internationale, Koninklijke Nederlandsche Wielren Unie and Federacion Espanola Ciclisimo. Preliminary Ruling Requested by the Arrondissementsrechtsbank Utrecht. Case 36-74. (online)]. 


\begin{tabular}{|c|c|c|c|c|}
\hline SEZÓNA & PREMIER & CHAMPIONSHIP & LEAGUE 1 & LEAGUE 2 \\
\hline $1995 / 96$ & 110 & 50 & 22 & 13 \\
\hline $1996 / 97$ & 135 & 59 & 26 & 14 \\
\hline $1997 / 98$ & 190 & 80 & 33 & 17 \\
\hline $1998 / 99$ & 285 & 82 & 42 & 20 \\
\hline $1999 / 00$ & 319 & 113 & 42 & 23 \\
\hline $2000 / 01$ & 396 & 138 & 42 & 24 \\
\hline $2001 / 02$ & 475 & 150 & 51 & 27 \\
\hline $2002 / 03$ & 548 & 149 & 48 & 26 \\
\hline $2003 / 04$ & 583 & 138 & 40 & 25 \\
\hline
\end{tabular}

Tabulka č. 2: Odhad celkových príjmů hráču v anglických fotbalových ligách v letech 1995/96-2003/04 (v milionech liber). Pozn. Odhady zahrnují př́spěvky na Národní pojištění, nikoli však částky plynoucí do hráčských penzijních fondů.

Zdroj: Deloitte in The Political Economy of Football: Estimated Total Players' Earnings English Football Leagues: 1995/96 to 2003/04 [2002]

\section{Střet zastánců amatérismu a profesionalismu}

Zavádění profesionalismu téměř nikde neprobíhalo hladce, jeho zastánci a odpůrci mezi sebou zpravidla sváděli tuhé boje. K hlubšímu porozumění strategiím a postojům aktérů na obou stranách konfliktu je třeba optikou teorie uznání Axela Honnetha [2004] stručně nastínit povahu proměny sociální struktury v konkrétní zemi, jako př́klad budou uvedeny Anglie a Německo.

Pro předmoderní společnosti je charakteristická jednota všech sfér uznání, v průběhu procesu modernizace se však postupně vyčleňují jednotlivé sféry uznání - láska (meziosobní ocenění), právo (princip rovnosti před zákonem) a sociální ocenění (společenskou hierarchií definovaný výkon). Charakteristickým rysem evropského procesu modernizace je podle Honnetha střet mezi upadající aristokracií, která legitimizovala svá privilegia vlastní urozeností a které se podařilo vtělit svůj etický kodex do právního systému (a tedy legislativně kontrolovat žádoucí podobu sportu jakožto společensky pozitivně sankcionovaného výkonu), a nastupující buržoazií, která navzdory své rostoucí ekonomické moci nedisponovala obdobnou politickou mocí a společenskou prestiží a musela bojovat za egalitarizaci právních norem a prosazení odlišných kritérií společenského ocenění. Zastávala proto ideologii vlastnictví a individuálního výkonu, projevujícího se především tržním úspěchem.

Tento střet se naplno projevil i v třídně strukturovaném anglickém fotbale konce 19. století. Aristokracie a vyšší střední třída, které ovládaly FA a mohly tak určovat pravidla a soutěžní předpisy, chtěly bojem proti profesionalismu udržet amatérskou elitní gentlemanskou podobu sportu. Obchodníci ze střední třídy vlastnili kluby a profesionalismus pro ně znamenal možnost vyšších zisků. Pro profesionální hráče fotbal představoval ojedinělou šanci na společenský vzestup a uznání na základě zásluh, které jim v jiných oblastech života bylo odepřeno, ačkoli byly možnosti dosažení vyššího statusu 
mimo jiné v důsledku autoritářského a přezíravého jednání ze strany klubového vedení značně omezené [Giulianotti 1999: 107].

Postoje k profesionalismu byly determinovány ideologiemi jednotlivých společenských vrstev i v Německu. Aristokracie zastávala tradiční elitářské amatérské pojetí sportu, jehož akcent na mezinárodní soutěžení stál i u zrodu moderních olympijských her. Nacionalisticko-konzervativní kruhy oceňovaly sport jako prostředek ke zušlechtování těla pro potřeby vojenské služby a posilování národního vědomí, mezinárodní soutěžení a profesionální sport však pokládaly za projev amerikanismu a dekadentní materialistické masové kultury. Krajní pravice dokonce rozlišovala mezi cvičením (hodným následování, přispívajícím k rozvoji ctností a tělesné sebekázně) a sportem (pro vybičování nízkých pudů, projevem barbarismu). Dělnické hnutí, vzniklé na konci 19. století, odmítalo profesionální sport jako projev kapitalistické ziskuchtivosti, sportovní internacionalismus měl sloužit $\mathrm{k}$ podpoře harmonického soužití národů. Profesionální fotbal tehdy nacházel své stoupence pouze v liberálních obchodnických kruzích [Brändle - Koller 2002: 87-88].

Navzdory houževnatému odporu zastánci amatérismu nakonec vždy tento boj prohráli, většinou kvůli rostoucí moci klubů, liberální hospodářské politice či sportovnímu zaostávání za zeměmi, které profesionalismus již povolily. Na jedné straně docházelo k poklesu společenského vlivu jeho tradičních odpůrců (aristokracie, armáda, nacionalisticko-konzervativní kruhy), kooptaci dělnického hnutí do systému a participaci dělníků na výdobytcích sociálního státu a vzestupu středních vrstev a obchodních kruhů, na straně druhé pokračoval proces generalizace trhu a postupné komodifikace téměř všech oblastí společenského života. Rozmach masových médií (zejména komerčních) a participace buržoazie ve světě politiky umocnila schopnost této vrstvy definovat obsah společensky uznaného výkonu v podobě tržního úspěchu, kterého stále lépe finančně ohodnocení nejlepší fotbalisté nesporně dosahovali. Všudypřítomnost masové kultury, jejíž integrální součástí sport byl od konce 19. století, spolu se symbolickou mocí vrcholných politiků oceňujících úspěšné sportovce přispěla ke zvýšení společenské prestiže profesionálních sportovců věnujících se všeobecně populárním sportům. Získaný symbolický kapitál umožnil vytvořit z profesionálních fotbalistů oficiální vzory pro mládež, což nakonec platilo v zásadě pro všechny významné moderní ideologie, snad s výjimkou maoismu. ${ }^{17}$

\section{Status nejlepších hráčů}

Ačkoli vyjednávací pozice hráčů byla dlouhou dobu slabá, od počátku zavedení pravidelných soutěží a zejména jejich mediálního pokrytí získávali nejlepší hráči status hrdinů. V období před 2. světovou válkou šlo v Anglii převážně o hrdiny dělnické třídy, kteří měli silné vazby na lokální komunitu obvykle tvořící jádro př́íznivců klubu, ve kterém dlouhodobě působili. Objevoval se také typ „gentlemana amatéra“ (nositele aristokratických hodnot), či „individualisty rebela“ [Kelly 2004: 2]. Působením masových médií se image fotbalistů přenášela k národnímu publiku [Kelly 2004: 153]. Po 2. světové válce popularita některých hráčů překročila hranice fotbalu a získali tak status superhvězd, zároveň se objevil nový typ „demokratického gentlemana“ (např. Stanley Matthews), v jehož

17 Podrobněji o proměně statusu fotbalistů od společenské marginality k piedestalu z pohledu Honnethovy teorie uznání viz [Hanuš 2008a]. 
osobě se kombinuje přirozený talent i snaha a skromnost [Woolridge 2002: 65]. Rostoucí komercializace fotbalu umožnila proměnu nejlepších fotbalistů na mezinárodní mediální hvězdy. Jak poznamenává Mike Featherstone, dříve byli hrdinové nositeli morálních vlastností a ztělesňovali hodnoty prostředí svého původu, u současných celebrit se naproti tomu klade důraz na vzhled a atraktivitu osobnosti, nikoli na charakter. Fotbalisté v roli celebrit nicméně představují nestálé zboží, především kvůli riziku zranění, absence na klíčových akcích, skandálům odrazujícím část publika [Featherstone in Giulianotti 1999: 116-119], či nestálosti sportovních výkonů, které jsou základem jejich přitažlivosti doma i na hřišti soupeře, na rozdíl od místních hrdinů, těžících ze své obecné popularity omezené místem jejich působiště [Brandes - Franck - Nüesch 2007]. Existence superhvězd dále prohlubuje stratifikaci mezi profesionálními fotbalisty.

Modelovým př́kladem fotbalové celebrity je David Beckham, jehož popularita mohla dosáhnout enormních rozměrů (nejvíce v Anglii, ale i v mnoha jiných zemích) z velké části díky struktuře anglického mediálního trhu. News Corporation Ruperta Murdocha kromě televizní společnosti BSkyB, která má zakoupena vysílací práva na zápasy Premier League, vlastní či kontroluje významnou část britského tisku (včetně nejčtenějšího bulvárního deníku The Sun). Díky tomu proniká fotbal (z velké části v podobě př́íběhů fotbalových celebrit a jejich rodin) i do ostatních oblastí zpravodajství a populární kultury, marketinkové strategie Manchesteru United podporují rozšiřování klubové popularity (a Beckhamova kultu) i mimo Anglii, zejména ve východní Asii. Kritici anglického „nového fotbalu“ hovoří o „kultuře posedlé celebritami“ [Williams 2006: 103].

Odklon od hodnot lokální komunity a důraz na vzhled a osobní image ilustruje vyvázání vrcholového fotbalu z kontextu „tady a ted““ a rostoucí globalizaci a komercializaci sportu. Zároveň ale svědčí o některých paradoxech soudobé společnosti: Beckham je jako fotbalista závislý na svém „fyzickém kapitálu“, na tom, zda bude jeho tělo jakožto výrobní nástroj schopno disciplinovaně podávat požadované výkony, nebơ nejistota profese fotbalisty nutí hráče ke striktnímu dodržování disciplíny včetně životosprávy [srv. Roderick 2006: 260-261] a zároveň klade na jejich tělo stále vyšší nároky, což často způsobuje chronické potíže a dlouhodobé následky [srv. Roderick - Waddington Parker 2000: 177-178], ale jako ikona reklamního a módního průmyslu a specifického životního stylu (metrosexuality) propaguje hodnoty hedonismu. Řečeno slovy Zygmunta Baumana: fotbalista Beckham je moderní dodavatel statků (a na hřišti je vězněm neméně moderního Panoptika), metrosexuál Beckham je postmoderní sběratel prožitků [Bauman 1995: 77-79]. Protikladnost a vzájemná neslučitelnost obou rolí je tedy jen zdánlivá.

Jiným př́kladem globální fotbalové celebrity je Diego Maradona. Nicolás SalazarSutil označuje kult jeho osobnosti termínem Maradona Inc. Nejedná se však podle něj o tradiční korporaci, ale o skutečnost, že jedince Maradonu vlastní sítě agentů, publik a trhů. Ideál Maradony, do kterého si může každý promítnout jakýkoli význam, nepatří jemu, ale „zmatku a kakofonii globální kultury“ [Salazar-Sutil 2008: 455-456]. V osobách globálních fotbalových celebrit se tak nejvýrazněji projevuje odtržení elitního fotbalu od dřívější lokální zakotvenosti.

\section{Fotbal jako mobilitní kanál}

Všestranné zlepšení společenského postavení fotbalistů, které nicméně neproběhlo ve všech zemích stejnou měrou, učinilo z fotbalu alternativní mobilitní kanál v protikladu 
ke vzdělání nebo podnikání. Hraní fotbalu tak umožňuje některým členům více či méně exkludovaných skupin obyvatel dosáhnout společenského vzestupu, v některých případech se dokonce orientace na profesionální sport stává hlavní, značně nejistou životní strategií [viz např. McGilivray - Fearn - McIntosh 2005: 120]. Význam fotbalu jakožto mobilitního kanálu se zvyšuje s rostoucí sociální nerovností, nedostatkem jiných příležitostí ke vzestupu, rozšířeností fotbalu, možností podchycení a rozvoje mladých talentů, výší odměn pro profesionální fotbalisty, jejich společenskou prestiží a ve většině případů otevřeností fotbalových pracovních trhů. V jednotlivých zemích se tyto faktory různým způsobem prolínají. V řadě chudých afrických zemí je fotbal všeobecně rozšířený, existuje zde vysoká míra nerovností a nedostatek př́ležitostí pro společenský vzestup, na druhé straně jsou zde ale omezené možnosti podchycení a rozvoje talentů. Rozvinuté evropské země mají více rovnostářskou sociální strukturu, která nabízí více alternativních možností vzestupu, jsou zároveň zde jsou lepší podmínky pro zachycení a výchovu talentovaných hráčů a vyšší platové ohodnocení profesionálních fotbalistů.

Dílčí aspekty a předpoklady sociální mobility hráčů fotbalu se staly předmětem řady odborných studií. Néstor Gandelman ukazuje na př́kladu uruguayského fotbalu, že existuje tendence spojení horších hráčů s horšími kluby a lepších hráčů s lepšími kluby, přičemž lepší výkon vede častěji ke kariérnímu postupu než horší výkon k sestupu. Dokud hráč poprvé nepřestoupí, má relativně menší šanci na postup (ale minimální na sestup), s rostoucím věkem se mobilita hráčů zvyšuje [Gandelman 2008: 365], ale po dovršení 28. let se možnosti pro přestup zhoršují. V rámci uruguayského fotbalu je rasová diskriminace vyšší než na celkovém pracovním trhu, což ale neplatí pro přestupy do zahraničí. Diskriminace se netýká př́ijmů, nebot výkony ne-bílých hráčů jsou odměňovány lépe, nýbrž menší šance získat profesionální smlouvu (tedy období přechodu od juniorů k profesionálům). Šance na přestup do zahraničí se zvyšuje, nastupuje-li hráč na ofenzivním postu či za národní tým [Gandelman 2009: 19]. Pozitivní diskriminace v odměňování se objevuje anglické Premier League, kde hráči pocházející z Jižní Ameriky často bývají přepláceni navzdory skutečnosti, že jejich početnější přítomnost může vést ke snížení výkonnosti týmu (za stejné peníze by klub mohl mít kvalitnější fotbalisty odjinud). Na druhé straně ale jejich účast zvyšuje návštěvnost utkání a tím i zisky z prodeje vstupenek [Pedace 2008: 137]. Rozhodnutí stát se profesionálním fotbalistou $\mathrm{s}$ sebou nese i vedlejší náklady v podobě obětovaných příležitostí pro hráče, kteří dosáhli vyššího vzdělání (napřr. v Uruguay dosahují lépe vzdělání hráči vyšších příjmů, protože při volbě profese fotbalisty musí být jejich výkonnost natolik vysoká, aby kompenzovala ušlé příležitosti, $v$ opačném případě se rozhodnou pro jiný obor - hráči s nižším vzděláním z méně zámožných rodin podobnou možnost volby nemají [srv. Gandelman 2009: 19]) a zároveň riziko obtížného uplatnění po ukončení sportovní kariéry, nebơ ve většině př́ípadu byla př́íprava pro vrcholový sport s kvalitním vzděláním obtížně slučitelná. Tento problém se některé státy (a později i řada větších klubů) pokoušely řešit prostřednictvím propojením sportu se školstvím, které by umožnilo zkvalitnit přípravu budoucích sportovců a zároveň poskytlo základ pro budoucí uplatnění na trhu práce. Ačkoli jeden z prvních sportovních internátů zaměřených na fotbal byl založen již v roce 1947 v tehdy sovětském Tbilisi (zde však nešlo primárně o výchovu elitních sportovců, nýbrž o řešení sociální situace nadměrného počtu sirotků způsobeného obrovskými ztrátami obyvatelstva za 2. světové války), systematičtěji se začalo sportovní internátní 
školství rozvíjet v padesátých letech v tehdejší Německé demokratické republice (NDR), odkud se v př́rštím desetiletí výrazněji rozšiřilo do Sovětského svazu (SSSR). Inspirace sovětským modelem se projevila i v jiných socialistických zemích v čele s Čínou, zároveň se ve stejné době rozvíjela alternativní podoba sportovních internátů ve Švédsku, Finsku a dalších zemích [Metsä-Tokila 2002: 199, 203]. Kombinace intenzivní fotbalové přípravy s kvalitním vzděláním vyžaduje dostatečně pružný vzdělávací program i převzetí větší části zodpovědnosti za ranou profesionalizace hráče a s ní spojená rizika ze strany klubů a sportovních organizací [Christiensen - Sørensen 2008: 455-456].

\section{Globální ekonomické nerovnosti uvnitř světa fotbalu}

Nerovnost mezi kluby se projevuje nejen uvnitř jednotlivých národních států, ale (ještě výrazněji) i na regionální, kontinentální a celosvětové úrovni. Pro hlubší porozumění povaze migrace a mobility fotbalistů je nezbytné nahlížet na problém z globální perspektivy. Obecně platí, že bohatší kluby z bohatších soutěží přitahují kvalitní hráče z chudších klubů a z chudších soutěží. Hlavní proud migrace hráčů tedy směřuje - z hlediska teorie světového systému - z periferních a semiperiferních oblastí směrem do jádra, zatímco šíření fotbalu probíhalo opačným směrem [Magee - Sugden 2002: 428]. Situaci vystihuje níže uvedené Schéma č. 2.

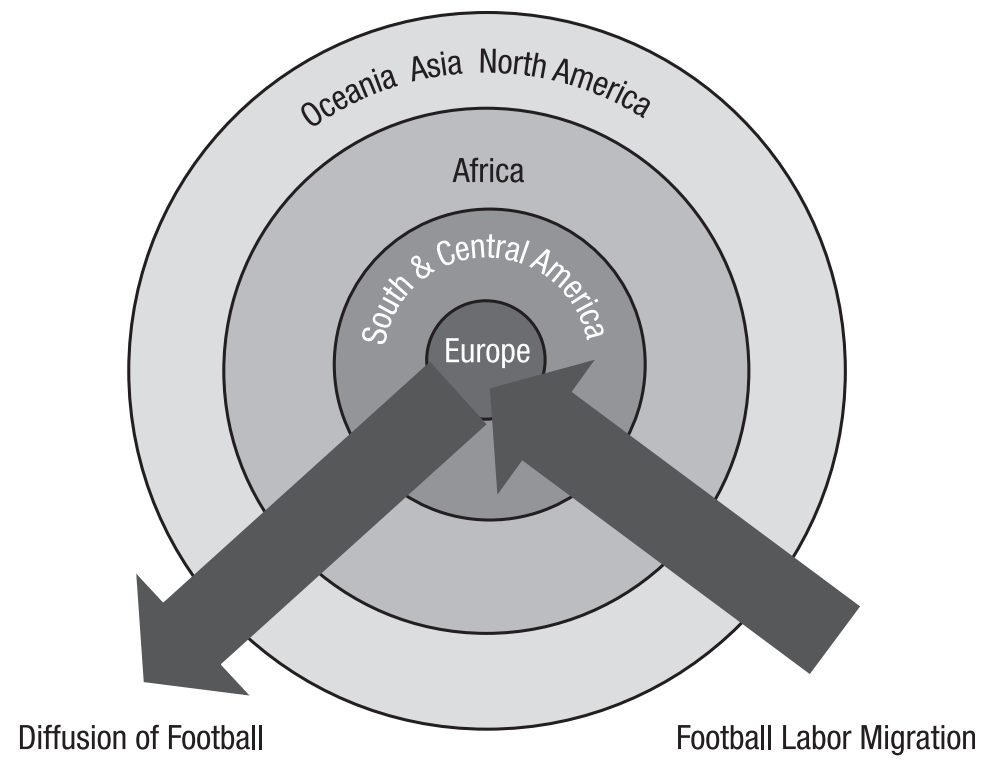

Schéma č. 2: Globálni šiření fotbalu a fotbalová pracovní migrace

Zdroj: Magee, Jonathan - Sugden, John. [2002]. „The World at their Feet“: Professional Football and International Labor Migration. Journal of Sport and Social Issues 26 (November 2002), No. 4, s. 428.

Intenzita mezinárodní fotbalové migrace se zvýšila v devadesátých letech liberalizací pracovního práva v Evropské unii, otevření pracovních trhů v postkomunistických 
zemích a v některých případech i jejich vstupu do Evropské unie. Specificky novým fenoménem v tomto období je zakládání fotbalových akademií v rozvojových, především afrických zemích, které mají evropským klubům v situaci stále rostoucích výdajů na přestupy a platy hráčů sloužit k získávání levných, často pod reálnou tržní cenou „nakupovaných“ kvalitních fotbalistů. Odchod největších talentů do evropských klubů ale snižuje úroveň domácích ligových a pohárových soutěží, v čemž někteří autoři spatřují jeden z projevů neokoloniální obdoby koloniální exploatace přírodních zdrojů [Darby Akindes - Kirwin 2007: 156-157].

Odchod domácích talentů do zahraničí a s ním související růst nerovností mezi kluby však může mít paradoxní důsledek v podobě snižování rozdílů mezi národními týmy, nebơ reprezentanti chudých zemí v zahraničí budou hrát v kvalitnějších týmech a nastupovat proti zdatnějším soupeřům, což povede ke zlepšení jejich výkonnosti [Milanovic 2005: 829]. Možný kompromis mezi získáváním zahraničních zkušeností a udržením kvality domácích klubových soutěží spatřuje Branko Milanovic v opatření často praktikovaném $\mathrm{v}$ jiných oborech, kdy mají hráči za každé čtyři odehrané roky doma možnost jednoho roku působení v zahraničí.

Takové opatření by ovšem bylo možné prosadit pouze globálně prostřednictvím mezinárodních institucí, nebot jednotlivé státy by se jej v důsledku obav o zhoršení vlastní pozice neodvážily samostatně zavést [Milanovic 2005: 846]. Bernd Frick nicméně zpochybňuje Milanovicovy závěry o zvyšování soutěžní rovnováhy v důsledku větší migrace hráčů, protože mimo jiné s ohledem na politickou nestabilitu a manažerskou nekompetentnost vedení fotbalových svazů v řadě rozvojových (a zvláště afrických) zemí si tradičně úspěšné země nadále udržují soutěžní výhodu [Frick 2009: 101]. Podle výzkumu Lamprechta a Stamma existuje poměrně silná vazba mezi ekonomickou silou země v kombinaci s dlouhou místní fotbalovou tradicí a sportovní výkonností. Dominance Evropy je zajištěna komplementaritou rozvinuté ekonomiky a dlouhé tradice, což zakládá její jádrovou pozici v rámci světového systému [Lamprecht a Stamm dle Darby 2000: 39]. Souvislost velikosti a bohatství země s úspěšností ve fotbale potvrzují i Michael A. Leeds a Eva Marikova-Leeds [2009: 387].

Obtížnost prosazení Milanovicova návrhu je tedy zřejmá, což vyvolává nutnost hledání alternativních forem regulace. Efektivnější řešení by spočívalo ve zlepšení ekonomické situace afrických klubů, které by tak byly schopné konkurovat evropským nabídkám, což předpokládá finanční nabídky, přilákání sponzorů a vyšší cenu televizních práv. Odchod nejlepších fotbalistů však snižuje kvalitu hry a tudíž i atraktivitu afrického fotbalu pro sponzory a televizi, obyvatelstvo žijící často pod hranicí chudoby navíc nepředstavuje koupěschopnou poptávku, která by byla atraktivní pro reklamní inzerenty, takže možnosti získání peněz z těchto zdrojů (tedy cestou volného trhu) jsou značně omezené. Možnosti rozvoje afrického fotbalu navíc kromě nedostatku financí (kvůli kterému africké týmy často ani nedokončí kvalifikaci na mistrovství světa) limituje rozsáhlá korupce, špatná organizace a politické zásahy, jakými jsou např. př́ležitostné rozpuštění národní asociace po špatných výsledcích [Darby - Akindes - Kirwin 2007: 157-158].

Na africkém př́kladu lze demonstrovat obecnější rysy vývoje fotbalu z globální perspektivy. Počáteční vývoj v koloniálním období je poznamenán kromě politické nadvlády také ekonomickým vykořistováním a částečně kulturním imperialismem, který byl ovšem v prŕípadě fotbalu většinou pozitivně přijat, a slabou rolí FIFA. V nekolonizova- 
ných nebo již emancipovaných oblastech se fotbal šíril převážně prostřednictvím migrace obyvatel, ovlivněné jádrovou pozicí britského impéria. Vývojovou dynamiku lze proto z velké části vysvětlit na základě závislostí a vztahu jádra, semiperiferních a periferních oblastí. Tento model nicméně nelze aplikovat mechanicky, nebot mezi jednotlivými oblastmi, regiony a aktéry existuje vícesměrná závislost. Rostoucí význam FIFA a kontinentálních federací, celosvětové rozširrení fotbalu a prosazení antisystémových emancipačních hnutí ve Třetím světě vedlo ke zvýšení vlivu rozvojových zemí uvnitř systému fotbalové politiky, založeném na principu „jedna země rovná se jeden hlas“. Nutnost získat podporu zemí tzv. Třetího světa při volbě prezidenta FIFA sice umožnila částečné zlepšení pozice rozvojových zemí, ale nadále se zde projevuje ekonomická, technická, materiální a organizační závislost na zemích jádra (především Evropy). Její zmenšení nebo odstranění však závisí (nejen v africkém případě) kromě eliminace zmíněných problémů v konečném důsledku i na roli v globální kapitalistické ekonomice, na vytvoření vlastní udržitelné vývojové strategie [Darby 2000: 55-56] a na schopnosti kolektivně prosazovat své zájmy [Darby 2003: 19].

Politická moc rozvojových zemí je však limitována nerovným ekonomickým postavením, nebơ v př́padě vyhrocení sporů s Evropou by hrozilo vystoupení členských států UEFA z FIFA (o kterém se již vedly neformální vážné rozhovory), což by v situaci, kdy se v Evropě uskuteční 80 \% světového obratu ve fotbalové ekonomice, pravděpodobně uvrhlo FIFA do finanční krize [Sugden - Tomlinson - Darby 1998: 311].

\section{Současné ekonomické problémy}

Rostoucí ekonomická síla největších klubů, související se zvyšující se cenou televizních práv, která v Anglii vedla ke vzniku Premier League, se na evropské úrovni projevila tlakem velkoklubů na liberalizaci existující struktury evropských klubových pohárů, jenž vyústil v požadavku na vytvoření Superligy, uzavřené soukromé soutěže největších evropských klubů (tzv. G14), která by měla zaručit stabilně vysoké zisky pro všechny zúčastněné. Ekonomické rozbory však tento efekt jednoznačně nepotvrzují [Solberg Gratton 2004: 80]. UEFA se proto rozhodla reformovat existující strukturu evropských pohárů (především Ligy mistrů) tak, aby zejména velkým klubům zajistila vysoké př́íjmy, které by méně ohrozilo předčasné vyřazení, což z části zajištuje přerozdělováním zisků z mistrovství Evropy [Bedřich 2006: 26]. UEFA si tak udržela kontrolu nad evropskými klubovými poháry, posílila jejich prestiž a zabránila úpadku národních ligových soutěží.

Ačkoli v devadesátých letech došlo k masivnímu nárůstu př́imu zejména v největších evropských ligách (jak ukazuje Graf č. 1), díky zvýšení výdajů na platy hráčů způsobeného růstem př́jmů z televizních práv, se prohloubila míra nerovností mezi jednotlivými kluby a mnoho menších týmů v řadě zemí se ocitlo ve finanční krizi. Tato situace ovšem nenastala ve všech zemích stejnou měrou. Ve Francii podléhají fotbalové kluby poměrně silné státní regulaci, nemohou např. nakupovat hráče nad svoje finanční možnosti, aby předešly deficitním rozpočtům. V Německu je v řadě klubů zmenšen prostor $\mathrm{k}$ finančním spekulacím díky vlastnické struktuře, kdy půjčky musí být osobně garantovány klubovým vedením. ${ }^{18}$ Ve Španělsku a Řecku naproti tomu vlády v řadě případů

18 Specifický francouzský způsob regulace fotbalu je založen na třech piliřích: solidaritě (přerozdělování př́ijmů z prodeje televizních práv mezi kluby), povinnosti zřizování tréninkových center pro kluby a finanční kontrole od státu [Gouguet - Primault 2006: 47]. Tento systém, zavedený po finančních 
pomáhají klubům ve finančních potížích. Obecně platí, že menší regulace vytváří více rizik, ale také více možností, jak dosáhnout úspěchu. Menší úspěšnost francouzských klubů v Lize mistrů proto snižuje atraktivitu francouzského řešení pro ostatní země, UEFA však vyžaduje pro kluby startující v evropských pohárech ekonomické záruky [Lago - Simmons - Szymanski 2006: 7-11].

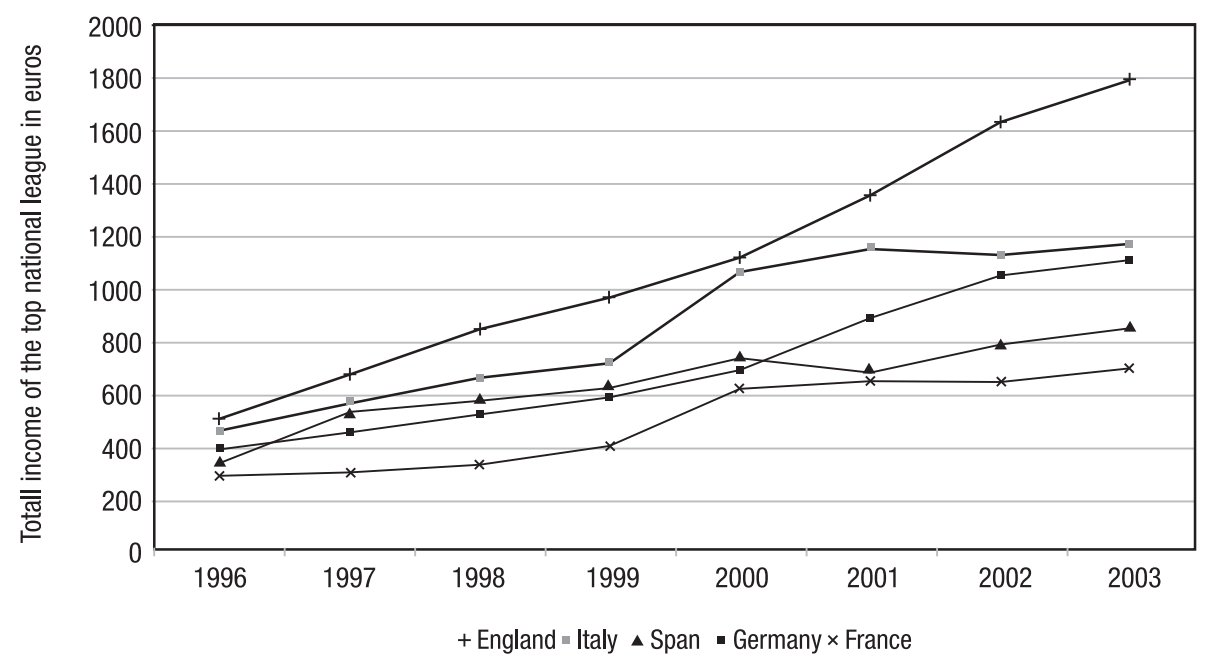

Graf č. 1: Růst př́ijmu ve vybraných evropských ligách v letech 1996-2003

Zdroj: Annual Review of Football Finance 2004 citovaný in Lago, Umberto - Simmons, Rob - Szymanski, Stefan. [2006]. The Financial Crisis in European Football: An Introduction. Journal of Sports Economics 7 (May 2006), s. 5.

Otázka regulace fotbalového průmyslu se stala významným tématem soudobých diskusí. ${ }^{19}$ Někteří autoři, např. Lago, Simmons a Szymanski [2006: 11] nabízejí jako alternativu kromě zmíněné Superligy také americký model, který však nemá oporu v tradičním evropském pojetí sportu a jeho prosazování by tak naráželo na značný odpor a vedlo by ke ztrátě důležitých společenských funkcí fotbalu. Tsjalle van der Burg naproti tomu navrhuje zákaz placených televizních přenosů při většině utkání, zrušení podpory pro profesionální kluby, tlak na kluby ve věci podpory sociálních projektů, striktní kontroly klubových rozpočtů a po podrobnější analýze za vhodné politické situace i speciální progresivní fotbalovou daň z klubových zisků. Tato opatření si kladou za cíl

problémech francouzských klubů na počátku devadesátých let, umožňuje francouzské reprezentaci dosahovat vynikajících výsledků navzdory relativně menšímu zájmu fanouškủ. Přesto se jak ve Francii, tak i v Německu (ale i v Anglii a Itálii) v posledních letech nachází řada klubů ve finanční krizi. Mezi příčiny patří v obou zemích mimo jiné nedůsledná kontrola klubového účetnictví, růst nerovnosti mezi vítězi a poraženými motivující $\mathrm{k}$ riskantnějším strategiím, ve Francii neexistence nezávislého auditora a v Německu slabé donucovací mechanismy a účetní standardy, umožňující skrývání klubových dluhů v některých př́padech až do vyhlášení bankrotu [Dietl - Franck 2007: 668; Andreff 2007: 660].

19 Podrobnější aktuální informace z ekonomiky fotbalu lze nalézt na adrese The Political Economy of Football, http://www.footballeconomy.com/ 
prevenci finančních krizí, udržení kompetitivní rovnováhy, sociálně kohezivních funkcí fotbalu a všeobecné dostupnosti kvalitních prožitků při sledování fotbalových zápasů. Nezbytným předpokladem je ovšem přístup na úrovni institucí EU, resp. UEFA [van der Burg 2000: 243-247].

Současná finanční krize ve světové ekonomice se ve fotbale projevila velmi nerovnoměrně, i když ve většině zemí zatím (v listopadu 2009) její dopady nejsou př́liš dramatické. $V$ anglické Premier League většina klubů v zájmu udržení návštěvnosti (úspěšně) zmrazila či snížila ceny sezónních vstupenek [Top Clubs Fend off Recession 2009]. V Zambii se ocitlo několik klubů po ztrátě sponzora (mědné společnosti) ve finančních obtížích poté, co v důsledku globální finanční krize prudce poklesla cena mědi [Fall in Copper Price Hits Zambian Clubs 2009].

\section{Závěr}

Cílem tohoto textu nebyla a ani nemohla být vyčerpávající analýza všech příčin, kontextů a dopadů komercializace fotbalu, ale spíše naznačení některých klíčových souvislostí tohoto fenoménu, v domácích společenských vědách poněkud opomíjeného. Proměny vztahu ekonomiky a společnosti v průběhu modernizace se výrazně promítly do téměř všech oblastí života a stranou nezůstal ani fotbal.

Fotbalové kluby i národní asociace zpočátku vznikaly primárně jako organizace na podporu sportu jakožto preferovaného způsobu trávení volného času či projev společenství a sdílených hodnot zakládajících skupin. Postupem doby se ukázalo, že stále rostoucí popularita fotbalu může být zdrojem zisku pro kluby i pro média, která mu začala věnovat stále větší pozornost. Na ekonomickém rozmachu fotbalu má klíčový podíl vznik televize, jejíž postupný rozvoj a všeobecné rozšíření podstatně stimulovaly rozmach sponzorství, vedoucí posléze ke zvyšování ceny televizních práv. Tento trend byl dále $\mathrm{v}$ mnoha zemích posílen přesunem fotbalu na soukromé, často placené, televizní kanály. Zvyšující se akumulace kapitálu uvnitř fotbalu vedla ke změně rovnováhy moci ve prospěch velkých klubů, sponzorů a televizních společností, k nutnosti přijetí tržních strategií i změně organizační a vlastnické struktury klubů. Špičkové kluby postupně začaly přejímat marketinkové strategie na podporu své značky, vedoucí k nové, více zákaznicky orientované podobě vztahu mezi fanouškem a klubem a v konečném důsledku k hlubšímu včlenění fotbalu do konzumní kultury. Na jedné straně tak dochází $\mathrm{k}$ pluralizaci podob identifikace $\mathrm{s}$ klubem, na druhé straně k oproštění od tradičních kulturních významů spjatých s konkrétním klubem, v některých segmentech fanoušků dochází k homogenizaci fotbalové kultury a k jeho celkové depolitizaci. Akumulace kapitálu uvnitř fotbalu, deregulace nejen televizních práv, ale i pracovního trhu přispěla k růstu nerovností mezi jednotlivými aktéry (kluby, hráči, fanoušky atd.) na úrovni jednotlivých států i v globálním měřítku a finančním problémům řady klubů, ačkoli v absolutních číslech jejich příjmy rostly. Z původně amatérských hráčů fotbalu se postupně stali profesionálové, zpočátku s omezenými právy a s finančním ohodnocením na úrovni kvalifikovaných dělníků. Růst ekonomického obratu, rozvoj televize a deregulace pracovního trhu vedly ke zvýšení př́imů hráčů zejména v bohatých klubech, zvýšené migraci i zlepšení sociálního statusu. Fotbal tak pro řadu talentovaných hráčů představoval alternativní mobilitní kanál. Z nejlepších hráčů, někdejších hrdinů lokálních komunit, se postupně staly globální celebrity. Řada kritiků si tak pokládá otázku, zda je možné 
považovat utkání ve vrcholovém sportu stále za hru, nebot - vzpomeneme-li Huizingovu definici hry ${ }^{20}$ - profesionalizovaný sport již nestojí mimo každodenní život a váží se na něj bezprostřední materiální zájmy.

Přesto ale fotbal, jakkoli v mnoha aspektech komercializovaný, nelze pokládat za zcela typickou oblast podnikání či běžné ekonomické odvětví. Na jedné straně fotbal díky nejistotě výsledků zdaleka nezaručuje spolehlivou návratnost investic (ačkoli jeho rostoucí ekonomický, společenský a politický význam zásadně přispěl k dnešní vysoké míre racionalizace hry) a loajalita fanoušků ke klubům výrazně omezuje elasticitu poptávky, čímž deformuje v teorii harmonickou tržní interakci nabídky a poptávky [viz Grant 2006]. Na straně druhé existují různé protitlaky vzdorující protržním tendencím, at už jde v konstruktivní poloze o hnutí za demokratizaci klubové správy či nové pokusy o ekonomickou regulaci na makroúrovni, nebo v destruktivní poloze - podle některých autorů, o fotbalové chuligánství nebo divácké skandování hesel typu „Nova kurví fotbal“.

20 Pod pojmem hra Huizinga rozumí „svobodné jednání, které je míněno 'jen tak' a stojí mimo obyčejný život, ale které přesto může hráče plně zaujmout, k němuž se dále nepřipíná žádný materiální zájem a jímž se nedosahuje žádného užitku, které se uskutečňuje ve zvlášt určeném čase a ve zvlášt určeném prostoru, které probíhá řádně podle určitých pravidel a vyvolává v život společenské skupiny, které se rády obklopují tajemstvím, nebo které se vymaňují z obyčejného světa tím, že se přestrojují za jiné [Huizinga 2000: 24-25].“ 


\section{Literatura}

Allan, Grant - Roy, Graeme. [2008]. Does Television Crowd Out Spectators?: New Evidence From the Scottish Premier League. Journal of Sports Economics 9 (December 2008), No. 6, s. 592-605.

Andreff, Wladimir. [2007]. French Football: A Financial Crisis Rooted in Weak Governance. Journal of Sports Economics 8 (December 2007), No. 6, s. 652-661.

Bauman, Zygmunt. [1995]. Úvahy o postmoderní době. Praha: SLON.

Bedřich, Ladislav. [2006]. Fotbal: rituální hra moderní doby. Brno: Masarykova univerzita.

Ben-Porat, Amir. [1998]. The Commodification of Football in Israel. International Review for the Sociology of Sport 33 (September 1998), No. 3, s. 269-276.

Ben-Porat, Amir. [2000]. Overseas Sweetheart: Israelis Fans of English Football. Journal of Sport and Social Issues 24 (November 2000), No. 4, s. 344-350.

Bílá kniha o sportu. [2007] [online]. Dostupné na serveru Ministerstva školství, mládeže a tělovýchovy.cz, < http://www.msmt.cz/uploads/souborz/TVS/2008/Bila_kniha_sport_cze.pdf > [25. 11. 2009]

Bourdieu, Pierre. [2002]. O televizi. Brno: Doplněk.

Brandes, Leif - Franck, Egon - Nüesch, Stephan. [2007]. Local Heroes and Superstars: An Empirical Analysis of Star Attraction in German Soccer. Journal of Sports Economics 0 (2007), No. 6, s. 1-21.

Brändle, Fabian - Koller, Christian. [2002]. Goal!: Kultur- und Sozialgeschichte des modernen Fussballs. Zürich: Orell Füssli Verlag AG.

Brick, Carlton. [2004]. Misers, Merchandise and Manchester United: The Peculiar Paradox of the Political Economy of Consumption. In. Andrews, David L. (ed.) Manchester United: A Thematic Study. London - New York: Routledge, s. 101-112.

Cave, Martin - Crandall, Robert W. [2001]. Sports Rights and the Broadcast Industry. The Economic Journal 111 (February 2001), No. 469, s. F4-F26.

Daflon, Rogerio - Ballve, Teo. [2004]. The Beautiful Game?: Race and Class in Brazilian Soccer. NACLA Report on the Americas 37 (March-April 2004), No. 5, s. 23-27.

Darby, Paul. [2000]. Africa's Place in FIFA's Global Order: A Theoretical Frame. Soccer \& Society 1(Summer 2000), No. 2, s. 36-61.

Darby, Paul. Africa, the FIFA Presidency, and the Governance of World Football: 1974, 1998, and 2002. Africa Today 50 (Spring 2003), No. 1, s. 3-24.

Darby, Paul - Akindes, Gerard - Kirwin, Matthew. [2007]. Football Academies and the Migration of African Football Labor to Europe. Journal of Sport and Social Issues 31 (2007), No. 2, s. $143-161$.

Derbaix, Christian - Decrop, Alain - Cabossart, Olivier. [2002]. Colors and Scarves: The Symbolic Consumption of Material Possessions by Soccer Fans. Advances in Consumer Research 29 (2002), No. 1, s. 511-518.

Dietl, Helmut M. - Franck, Egon. [2007]. Governance Failure and Financial Crisis in German Football. Journal of Sports Economics 8 (December 2007), No. 6, s. 662-669.

Dobson, Stephen - Goddard, John. [2001]. The Economics of Football. Cambridge: Cambridge University Press.

Duke, Vic. [2005]. Perestroika in Progress?: The Case of Spectator Sports in Czechoslovakia. The British Journal of Sociology 41 (June 1990), No. 2, s. 145-156.

Fall in Copper Price Hits Zambian Clubs [2009]. [online]. Dostupné na The Political Economy of Football.com., < http://www.footballeconomy.com/world.htm > [18. 3. 2009]

Foster, Ken. [2005]. Alternative Models for the Regulation of Global Sports. In. Allison, Lincoln. (ed.) The Global Politics of Sport: The Role of Global Institutions in Sport. London - New York: Routledge, s. 63-86.

Frick, Bernd. [2009]. Globalization and Factor Mobility: The Impact of the „Bosman-Ruling“ on Player Migration in Professional Soccer. Journal of Sports Economics 10 (February 2009), No. 1, s. 88-106. 
Gandelman, Nestor. [2008]. Mobility Among Employers and Assortative Matching: Field Evidence From Soccer Data. Journal of Sports Economics 9 (August 2008), No. 4, s. 351-370.

Gandelman, Nestor. Selection Biases in Sports Markets. Journal of Sports Economics 0 (March 2009), No. 0, s. 1-20.

Giulianotti, Richard. [1999]. Football: A Sociology of the Global Game. Cambridge: Polity Press.

Giulianotti, Richard. [2002]. Supporters, Followers, Fans, and Flaneurs: A Taxonomy of Spectator Identities in Football. Journal of Sport and Social Issues 26 (November 2002), No. 2, s. 25-46.

Giulianotti, Richard. [2005]. Sport Spectators and the Social Consequences of Commodification: Critical Perspectives from Scottish Football. Journal of Sport and Social Issues 29 (November 2005), No. 4, s. 386-410.

Giulianotti, Richard - Armstrong, Gary. [2001]. Afterword Constructing Social Identities: Exploring the Structured Relations of Football Rivalries. In. Giulianotti, Richard - Armstrong, Gary. (eds.) Fear and Loathing in World Football. Oxford - New York: Berg, s. 267-269.

Giulianotti, Richard - Robertson, Roland. [2007]. Forms of Glocalization: Globalization and the Migration Strategies of Scottish Football Fans in North America. Sociology 41 (April 2007), No. 2, s. 133-152.

Gouguet, Jean-Jacques - Primault, Didier. [2006]. The French Exception. Journal of Sports Economics 7 (February 2006), No. 2, s. 47-59.

Grant, Wyn. [2006]. Is Political Economy of Football Possible? [online]. Dostupné na The Political Economy of Football.com, < http://www.footballeconomy.com/academic_paper1.htm > [25. 11. 2009]

Hanuš, Karel. [2008a]. Fotbal a společenská modernizace. Diplomová práce na Filozofické fakultě Univerzity Karlovy v Praze, Katedra sociologie.

Hanuš, Karel. [2008b]. Fotbal v procesu modernizace: od patologie k profesionalismu. In. Trendy sociálně patologických jevů. Sborník př́spěvků ze semináre sekce sociální patologie MČSS Kašperské Hory 23.-25. dubna 2008. Praha: Masarykova česká sociologická společnost, s. 215-219.

Hare, Geoff. [1999]. „Get Your Kit on for the Lads“: Adidas versus Nike, the Other World Cup. Sociology of Sport Online [online], Vol. 2 (1999), No. 2. Dostupné na < http://physed.otago.ac.nz/ sosol/v2i2/v2i2a1.htm > [14. 7. 2008]

Hare, Geoff. [2003]. Football in France: A Cultural History. Oxford - New York: Berg.

Hargreaves, John. [1987]. Sport, Power and Culture: A Social and Historical Analysis of Popular Sports in Britain. Cambridge: Polity Press.

Harris, Lloyd C. - Ogbonna, Emmanuel. [2008]. The Dynamics Underlying Service Firm-Customer Relationships: Insights From a Study of English Premier League Soccer Fans. Journal of Service Research 10 (May 2008), No. 4, s. 382-399.

Heinilä, Kalevi. [1989]. The Sports Club as a Social Organization in Finland. International Review for the Sociology of Sport 24 (March 1989), No. 1, s. 225-248.

Honneth, Axel. [2004]. Přerozdělování jakožto uznání: odpověd’ adresovaná Nancy Fraserové. In. Fraserová, Nancy - Honneth, Axel. Přerozdělování nebo uznání? Praha: Filosofia, s. 143-244.

Honneth, Axel. [2007]. Organizovaná seberealizace. Paradoxy individualizace. In. Honneth, Axel. (ed.) Zbavovat se svéprávnosti: paradoxy současného kapitalismu. Praha: Filosofia, 2007, s. $175-196$.

Horne, John - Manzenreiter, Wolfram. [2004]. Football, Culture and Globalisation: Why Professional Football Has Been Going East. In. Manzenreiter, Wolfram - Horne, John. (eds.) Football Goes East: Business, Culture, and the People's Game in China, Japan, and South Korea. New York, London: Routledge, s. 1-17.

Howard, Sophie - Sayce, Rhiannon. [2002]. Fact Sheet 11 : Branding, Sponsorship and Commerce in Football [online]. Dostupné na University of Leicester.uk, < http://www.le.ac.uk./socio$\operatorname{logy} / \mathrm{css} /$ resources/factsheets/fs $11 . h t m l>$ [14. 7. 2008]

Huizinga, Johan. [2000]. Homo ludens: o původu kultury ve hře. Praha: Dauphin.

Christensen, Mette K. - Sørensen, Jan K. [2009]. Sport or School? Dreams and Dilemmas for Talented Young Danish Football Players. European Physical Education Review 15 (February 2009) No. 1, s. 115-133. 
Ichirō, Hirose. [2004]. The Making of a Professional Football League: The Design of the J. League System. In. Manzenreiter, Wolfram - Horne, John. (eds.) Football Goes East: Business, Culture, and the People's Game in China, Japan, and South Korea. New York - London: Routledge, s. 38-53.

Jeřábek, Luboš. [1991]. Československý fotbal v čislech a faktech. Praha: Olympia.

Jones, Robin. [2004]. Football in the People's Republic of China. In. Manzenreiter, Wolfram Horne, John. (eds.) Football Goes East: Business, Culture, and the People's Game in China, Japan, and South Korea. New York - London: Routledge, s. 54-66.

Judgment of the Court of 12 December 1974. B. N. O. Walrave and L. J. N. Koch v Association Union Cycliste Internationale, Koninklijke Nederlandsche Wielren Unie and Federacion Espanola Ciclisimo. Preliminary Ruling Requested by the Arrondissementsrechtsbank Utrecht. Case 36-74. [online]. Dostupné na Odbor kompatibility s právem ES. Úřad vlády ČR, < http:// www.vlada.cz/ > [7. 2. 2010]

Kelly, Graham. [2004]. Terrace Heroes: The Life and Times of the 1930's Professional Footballer. London - New York: Routledge.

Kleinová, Naomi. [2005]. Bez loga. Praha: Argo, Dokořán.

Kuper, Simon. [2005]. Fotbal proti nepríteli. Praha: BB/art.

Lee, Simon. [1998]. Grey Shirts to Grey Suits: The Political Economy of English Football in the 1990's. In. Brown, Adam. (ed.) Fanatics!: Power, Identity and Fandom in Football. London New York: Routledge, s. 32-49.

Lago, Umberto - Simmons, Rob - Szymanski, Stefan. [2006]. The Financial Crisis in European Football: An Introduction. Journal of Sports Economics 7 (November 2006), No. 2, s. 3-12.

Leeds, Michael A. - Marikova Leeds, Eva. [2009]. International Soccer Success and National Institutions. Journal of Sports Economics 10 (August 2009), No. 4, s. 369-390.

Magee, Jonathan - Sugden, John. [2002]. „The World at their Feet“: Professional Football and International Labor Migration. Journal of Sport and Social Issues 26 (November 2002), No. 4, s. 421-437.

Making Football Affordable. [2009]. [online]. Dostupné na The Political Economy of Football. com, <http://www.footballeconomy.com/index.htm > [9. 10. 2009]

Mareš, Miroslav - Smolík, Josef - Suchánek, Marek. [2004]. Fotbaloví chuligáni: evropská dimenze subkultury. Brno: Barrister \& Principal.

McGillivray, David - Fearn, Richard - McIntosh, Aaron. [2005]. Caught up in and by the Beautiful Game: A Case Study of Scottish Professional Footballers. Journal of Sport and Social Issues 29 (February 2005), No. 2, s. 102-123.

Metsä Tokila, Timo. [2002]. Combining Competitive Sports and Education: How Top-Level Sport Became Part of the School System in the Soviet Union, Sweden and Finland. European Physical Education Review 8 (October 2002), No. 3, s. 196-206.

Milanovic, Branko. [2005]. Globalization and Goals: Does Soccer Show the Way? Review of International Political Economy 12 (December 2005), No. 5, s. 829-850.

Müller, Floris - van Zoonen, Liesbet - de Roode, Laurens. [2008]. We can't 'Just do it' alone! An analysis of Nike's (potential) contributions to anti-racism in soccer. Media, Culture \& Society 30 (January 2008), No. 1, s. 23-39.

Oppenhuisen, Joke - van Zoonen, Liesbet. [2006]. Supporters or Customers?: Fandom, Marketing and the Political Economy of Dutch Football. Soccer \& Society 7 (Spring 2006), No. 1, s. 62-75.

Pedace, Roberto. [2008]. Earnings, Performance, and Nationality Discrimination in a Highly Competitive Labor Market as An Analysis of the English Professional Soccer League. Journal of Sports Economics 9 (April 2008), No. 2, s. 115-140.

Pickford, Raplh W. [1940-1941]. The Psychology of the History and Organization of Association Football: Part I. British Journal of Psychology No. 31 (1940-1941), s. 80-93.

Polanyi, Karl. [2006]. Velká transformace. Brno: CDK.

'Pool Do the Deal [2009]. [online]. Dostupné na The Political Economy of Football.com., < http:// www.footballeconomy.com/index.htm > [9. 10. 2009] 
Price Takers rather than Price Makers [2009]. [online]. Dostupné na The Political Economy of Football.com., < http://www.footballeconomny.com/index.htm > [9. 10. 2009]

Ravenel, Loic - Durand, Christophe. [2004]. Strategies for Locating Professional Sports Leagues: A Comparison between France and Korea. In. Manzenreiter, Wolfram - Horne, John. (eds.) Football Goes East: Business, Culture, and the People's Game in China, Japan, and South Korea. New York - London: Routledge, s. 21-37.

Robertson, Craig. [2004]. A Sporting Gesture?: BSkyB, Manchester United, Global Media, and Sport. Television \& New Media 5 (November 2004), No. 11, s. 291-314.

Roderick, Martin. [2006]. A Very Precarious Profession: Uncertainty in the Working Lives of Professional Footballers. Work, Employment \& Society 20 (June 2006), No. 6, s. 245-265.

Roderick, Martin - Waddington, Ivan - Parker, Graham. [2000]. Playing Hurt: Managing Injuries in English Professional Footbal. International Review for the Sociology of Sport 35 (May 2000), No. 2, s. $165-180$.

Ross, Andrew. [2004]. Trouble at the Mill: Nike, United and the Asian Garment Trade. In. Andrews, David L. (eds.) Manchester United: A Thematic Study. London - New York: Routledge, s. 97-100.

Salazar-Sutil, Nicolás. [2008]. Maradona Inc: Performance politics off the pitch. International Journal of Cultural Studies 11 (December 2008), No. 4, s. 441-458.

Sandvoss, Cornel. [2003]. A Game of Two Halves: Football, Television and Globalisation. London - New York: Routledge.

Solberg, Harry Arne - Gratton, Chris. [2004]. Would European Soccer Clubs Benefit from Playing in a Super League? Soccer \& Society 5 (Spring 2004), No. 1, s. 61-81.

Sugden, John - Tomlinson, Alan - Darby, Paul. [1998]. FIFA versus UEFA in the Struggle for the Control of World Football. In. Brown, Adam. (ed.) Fanatics! Power, Identity and Fandom in Football. London - New York: Routledge, s. 11-31.

The Political Economy of Football: Estimated Total Players' Earnings English Football Leagues: 1995/96 to 2003/04 [2002]. [online]. Dostupné na The Political Economy of Football.com., < http://www.footballeconomy.com/stats/stats_turnover_16.htm > [15. 7. 2008]

Top Clubs Fend off Recession. [2009]. [online]. Dostupné na The Political Economy of Football. com., < http://www.footballeconomy.com/index.htm > [9. 10. 2009]

van der Burg, Tsjalle. [2000]. Football and Market Failure. New Economy 7 (December 2000), No. 4, s. 242-247.

Whannel Garry. [2009]. Television and the Transformation of Sport. The Annals of the American Academy of Political and Social Science 625 (September 2009), s. 205-218.

Williams, John. [2006]. 'Protect Me From What I Want': Football Fandom, Celebrity Cultures and 'New' Football in England. Soccer \& Society 7 (Spring 2006), No. 1, s. 96-114.

Williams, John - Neatrour, Sam. [2002]. Fact Sheet 10: The 'New' Football Economics [online]. Dostupné na < http://www.le.ac.uk./sociology/css/resources/factsheets/fs10.html > [14. 7. 2009]

Woolridge, Joyce. [2002]. Mapping the Stars: Stardom in English Professional Football 1890-1946. Soccer \& Society 3 (Summer 2002), No. 2, s. 51-69.

Yarar, Betül. [2005]. Hegemonic Struggle, the State and Popular Culture: The Case of Football in Turkey. European Journal of Cultural Studies 8 (February 2005), No. 5, s. 197-216.

Znebejánek, František. [1997]. Sociální hnutí: teorie, koncepce, představitelé. Praha: SLON.

Karel Hanuš (1984) vystudoval sociologii na Filozofické fakultě Univerzity Karlovy v Praze. Od roku 2008 studuje iberoamerikanistiku na téže fakultě a v letním semestru 2010 na Universidad Autónoma de Madrid. V současné době se kromě vztahu fotbalu a modernizace společnosti věnuje problematice teorie závislosti. 